\title{
A systems-based assessment of Palestine's current and future infrastructure requirements
}

Ives, M.C. ${ }^{1 *}$, Hickford, A.J. ${ }^{2}$, Adshead, D. ${ }^{1}$, Thacker, S. ${ }^{1,3}$, Hall, J.W. ${ }^{1}$, Nicholls, R.J. ${ }^{2}$ Sway, T. $^{3}$, Abu Ayyash, M. ${ }^{3}$, Jones, R. ${ }^{3}, \mathrm{O}^{\prime}$ Regan, N. ${ }^{3}$

1. School of Geography and the Environment, University of Oxford

2. Engineering and the Environment, University of Southampton

3. United Nations Office for Project Services

\section{Abstract}

The occupied Palestinian territories of West Bank and Gaza Strip are currently experiencing many challenges in the provision of infrastructure services for their inhabitants. This includes an undersupply of infrastructure services across multiple sectors - an issue exacerbated by population growth, increasing urbanisation, economic growth and climate change. We address this challenge by providing a systemsbased assessment of Palestine's infrastructure requirements and identifying broad strategies for how those needs might be met. This assessment involved four key components including: 1) defining and assessing the current system and planned infrastructure investments; 2 ) assessing potential future demand for infrastructure services; 3 ) identifying alternative strategies for future infrastructure provision beyond planned investments; and 4) analysing the performance of each strategy against a series of key performance indicators. Results from the assessment highlight the magnitude of the current and future need for urgent infrastructure investment in Palestine. The most immediate need is to alleviate the water crises in Gaza Strip, which will require at least twice as much water infrastructure investment over the coming decade than is currently in the pipeline, even if the goal is only to achieve the most basic World Health Organisation water availability requirements. To move beyond this protracted state of crises will then require a doubling of investments across all sectors to bring Palestine up to the standards of services already enjoyed by its neighbours. Such investments can have even greater impact on delivery of infrastructure services through the strategic use of interdependencies between infrastructure sectors, such as water re-use and energy-from-waste. In the pursuit of global sustainable development, the systems-based approach presented here provides an important first step in the assessment of infrastructure needs and opportunities for any country. It is particularly important for states like Palestine where key resources, such as water and energy, are so acutely constrained.

Keywords: system-of-systems; infrastructure services; interdependencies; long-term performance; decision-making under uncertainty

\section{Introduction}

Infrastructure is comprised of those basic physical and organisational structures, facilities and services that provide the foundation for economic productivity, connecting humans with their environment and allowing cities and countries to function. It augments human welfare through the provision of basic needs such as water, energy and waste management, and provides trade, mobility and access to services through transport and digital communications.

Palestine occupies parts of the western Levant region north of the Arabian Peninsula, and is comprised of two distinct territories separated by the State of Israel: the West Bank, a 5,655 km² territory bordering Israel to the north, west, and south and Jordan and the Dead Sea to the east; and the smaller Gaza Strip 
$\left(365 \mathrm{~km}^{2}\right)$, located on the eastern coast of the Mediterranean sharing borders with Israel and Egypt (Figure 1).

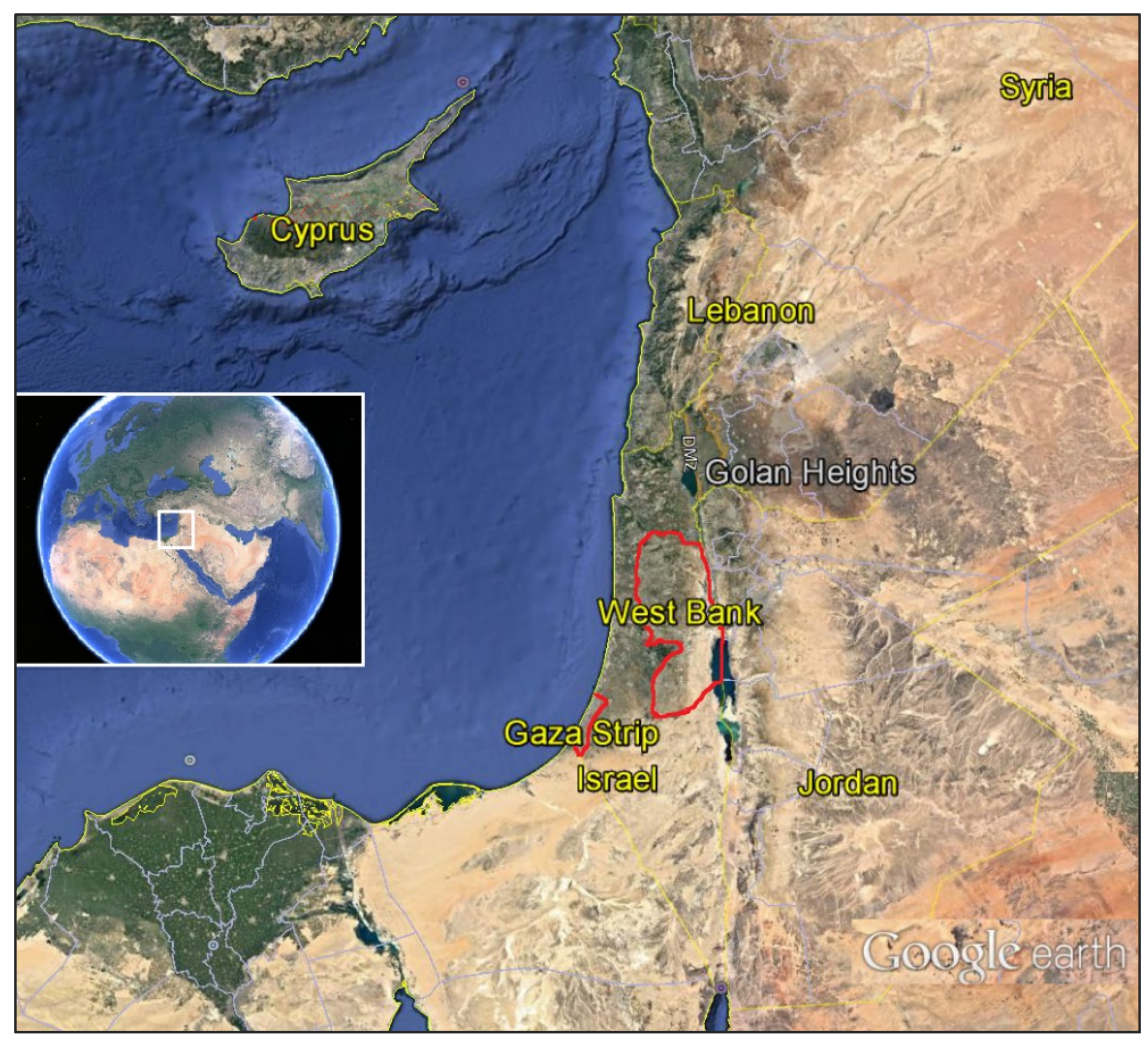

Figure 1: A satellite image of the Levant region with the outlines of the occupied Palestinian territories of Gaza Strip and the West Bank shown in red. (Source: Google Earth, 2017)
The occupied Palestinian territories of West Bank and Gaza Strip are experiencing many ongoing challenges in the provision of infrastructure services for their inhabitants. In fact, the modern Palestinian people have experienced such a protracted state of crises that characteristics which are common to post-conflict environments, such as refugee camps and damaged or disabled infrastructure assets, have become a part of everyday life. While the provision of infrastructure can enhance social wellbeing, the lack of such infrastructure services can conversely lead to declining health and wellbeing, diminished economic productivity and reduced social freedom.

The difficulties of the Palestinian people have not gone unnoticed by the international community with many countries providing hundreds of millions of dollars in funding and support over recent decades (World Bank Group, 2018). There has also been extensive research undertaken to understand the infrastructure requirements for Palestine in water supply (Bohannon, 2006; Brooks and Trottier, 2010; EWASH, 2015; Haddad, 2009; Ludwig, 2016; McNeill et al., 2009; PWA, 2011, 2012, 2014; Shadeed and Almasri, 2010; Shomar, 2011; Shomar et al., 2010; Weibel and Elmughanni, 2014; World Bank, 2009, 2015); in energy supply (Abu Hamed et al., 2012; De Meij et al., 2016; Evans, 2015; Henderson, 2014; Ibrik, 2009; Juaidi et al., 2016; MAS, 2014; UNISPAL, 2007; World Bank, 2014a, 2017); in wastewater management (Abusharbak, 2004; Dotan et al., 2016; Fatta et al., 2004; Nassar, 2015); in solid waste management (D-Waste, 2014; El Baba et al., 2015; Isaac et al., 2005; Sa'di); in transport (Garb, 1998; MoPWH, 2012; Suisman et al., 2005); and in digital communications (Paltrade, 2010; World Bank, 2016). Our analysis suggests these research efforts have been well prioritised in water and energy, with emphasis appropriately given to the acute crisis in the Gaza Strip.

Whilst this past research have provided useful input into the performance of Palestine's present and future infrastructure requirements for individual infrastructure sectors, such single-sector approaches risk ignoring key interdependencies between sectors. More recently, researchers and agencies have begun to look across multiple sectors to fill these gaps. However, due to their inherent complexities such analyses have been limited to just two sectors, such as water and wastewater (Afifi, 2006; Eting, 2015; Fatta et al., 2004; McNeill et al., 2009; PWA, 2012; Shomar, 2011), water and energy (PWA, 2015), and energy and waste (Ouda, 2013). Analyses looking at the water and energy nexus have also been conducted at a 
Middle East regional level to allow for resources to be shared and traded across borders (Gabriel et al., 2016; Siddiqi and Anadon, 2011).

A number of organisations have also begun providing cross-sectoral analyses for Palestine that include an assessment of most of the main infrastructure sectors (IMF, 2015, 2016; Office of the Quartet, 2016; State of Palestine, 2015). However, these assessments extend only as far as the current pipeline of proposed infrastructure projects and do not evaluate long-term requirements in alignment with the lifespan of most built infrastructure assets.

Methodologies for assessing national long-term infrastructure needs are similarly plentiful in individual infrastructure sectors but rare in terms of consistent systematic frameworks that can be applied across all infrastructure sectors. Researchers such as Pant (2018) and Kabat et al. (2005) have developed approaches for assessing exposure of infrastructure assets across different sectors to future risks, primarily flooding. (Masood et al., 2016) have provided a conceptual framework for the development of criteria and assessment methods for future-proofing infrastructure. Otto et al. (2014) have pioneered the only cross-sectoral approach for assessing national long-term infrastructure investment needs. Framed in terms of decision-making under uncertainty this approach has been successfully applied to the United Kingdom (Hall et al., 2016a). This comprehensive approach is ostensibly applicable to any chosen region. We apply this methodology here to the Palestinian context incorporating Palestine's unique set of socioeconomic and political conditions to assess five of Palestine's major infrastructure sectors including water, energy, transport, wastewater and waste to $2050^{1}$.

\section{Methodology}

The aim of this research is to provide a "fast track" analysis or broad understanding of a nation's current and future infrastructure requirements and develop strategies for understanding Palestine's future requirements. Infrastructure assets are generally long-lived, requiring significant capital investment with long lead-times. Planning for future investments is made challenging by the technological, environmental, and socio-economic uncertainties inherent in long-term projections. To simulate this challenge, we apply the system-of-systems assessment methodology developed in Otto et al. (2014), and extended by Hickford et al. (2015), to assess the performance of a broad assortment of strategies for infrastructure provision to meeting the needs implied by a range of long-term exogenous future scenarios.

The methodological framework is applied here through four key steps presented stylistic in Figure 2:

1) Evaluate the current infrastructure system and any planned investments;

2) Assess the potential future requirements for infrastructure by developing scenarios of key drivers of demand for infrastructure services;

3) Devise of a small number of alternatives strategies for delivering infrastructure services to meet the demands presented by each scenario;

4) Apply system models to produce performance indicators to assess the performance of each strategy over the scenarios of uncertainty.

In applying the Otto et al. (2014) framework, we also make use of their intentional terminology. Specifically, the term "scenarios" in the above process steps is used exclusively to describe the main exogenous drivers of change, factors outside the direct control of infrastructure decision-makers, which

\footnotetext{
${ }^{1}$ Digital communications is also considered a major infrastructure sector but was not included here due to insufficient being available on Palestine's privately owned and operated communications networks.
} 
influence the future demand of infrastructure services, and affect the impact and performance of the strategies of infrastructure provision (Hickford et al., 2014). These drivers are explored in consultation with stakeholders who identified demographic and economic change as being the main relevant drivers, though both of these are influenced by the security situation in the occupied Palestinian territories.

The term "strategies" is used to describe the alternative investment or intervention choices and policies around infrastructure provision in Palestine that are available to decision makers, focusing on the levels of investment for infrastructure provision in the different sectors, and the level of ambition that such investments represent.

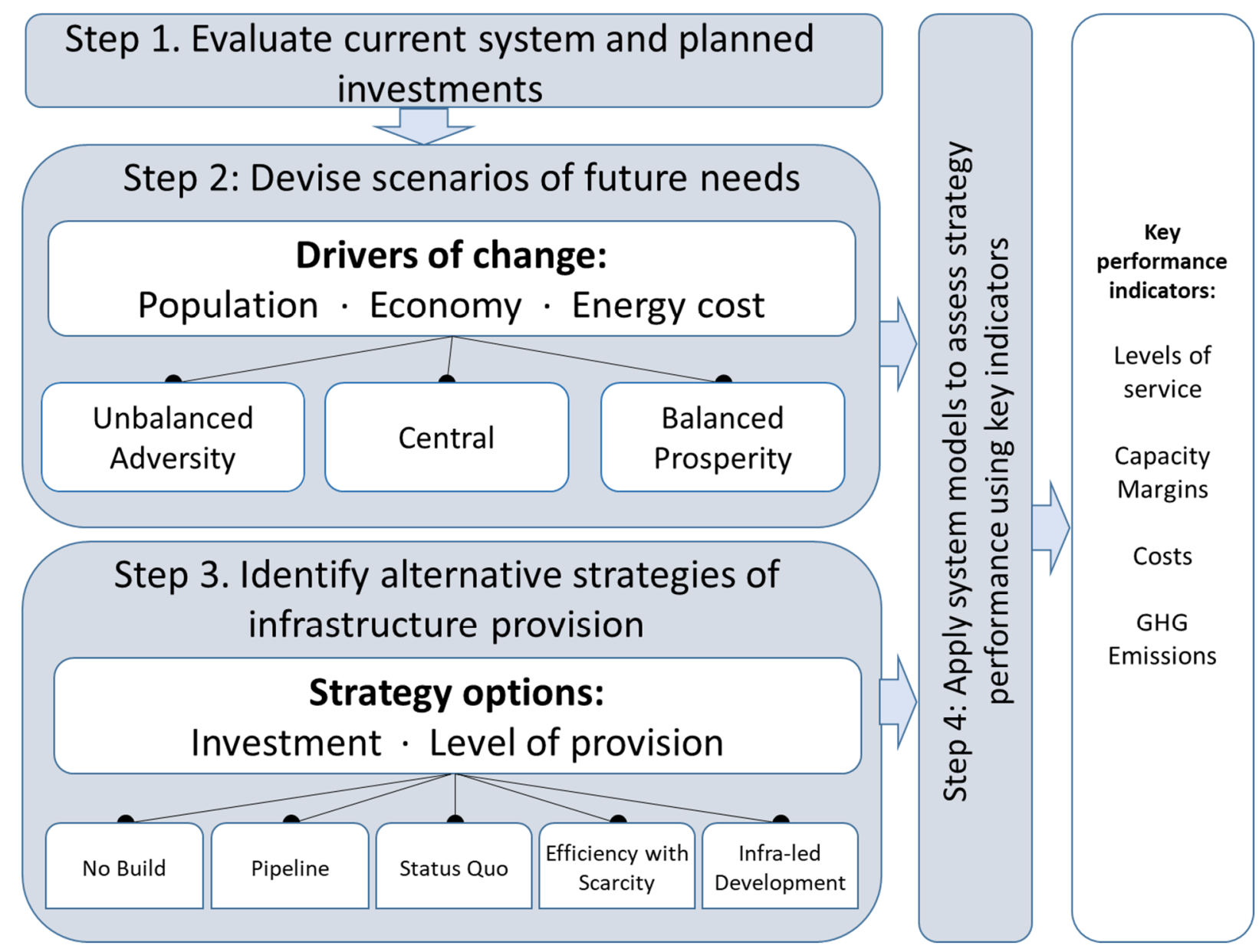

Figure 2: A stylised representation of the four steps of the assessment framework utilised in this study, including the use of scenarios, strategies, system models and key performance indicators.

The "system models" are computer models that take as inputs the current state of the infrastructure system and the demands placed upon them, as dictated by the scenarios, and invest in new infrastructure according to the chosen strategy. The models' outputs include a short list of key cross-sectoral performance indicators or metrics that are used to evaluate the performance of each strategy.

\section{Socio-economic scenarios}

The population of Palestine has grown very rapidly over the past two decades, from 2.7 million in 1997 to 4.8 million in 2016; roughly half the population is aged under 20 (54\% in Gaza and 48\% in the West Bank) and nearly $40 \%$ is younger than 15 years old (PCBS, 2015g). Hence, future demands for infrastructure services are highly sensitive to future demographic trends. In order to represent such uncertainty this report defines three alternative scenarios based on historic trends, taking the highest, lowest, and 
average observed population growth rates in governorates of both Gaza and the West Bank, resulting in a projected range of between 10.7 and 16.3 million people living in Palestine in 2050.

Short-term economic scenarios developed by the Palestine government (State of Palestine, 2015) are used to develop longer-term scenarios of economic growth (to 2050). This provides a range of economic activity and investment availability from a pessimistic growth rate of $1.5 \%$ of annual GDP growth, through a central rate of $3.5 \%$ annual GDP growth, to an optimistic rate of $5.5 \%$ annual GDP growth. The extent to which these drivers affect demand for infrastructure services is based on recent historic trends. In some cases, as with energy demand, historic trends have meant that demand has increased only with population growth and not economic growth. Such an approach is crude but considered sufficient for the purposes of this fast track analysis.

These scenarios of socio-economic uncertainty are combined into three composite scenarios as shown in Table 1. These scenarios of plausible futures (Ramírez and Selin, 2014) can be described as follows:

Table 1: the annual percentage increases in population and economic (GDP) growth associated with each scenario

\begin{tabular}{|c|c|c|c|}
\hline Scenario & \multicolumn{2}{|c|}{ Population growth } & Economic growth \\
\hline & Gaza & West Bank & \\
\hline Unbalanced Adversity & $+4.0 \%$ & $+3.4 \%$ & $1.5 \%$ \\
\hline Central & $+3.4 \%$ & $+2.6 \%$ & $3.5 \%$ \\
\hline Balanced Prosperity & $+3.1 \%$ & $+1.8 \%$ & $5.5 \%$ \\
\hline
\end{tabular}

Unbalanced Adversity accounts for the possibility of worsening conditions, with high population growth, deterioration in both the economic and political situation, and a slow process of reconciliation between the West Bank, the Gaza Strip and neighbouring countries.

The Central scenario assumes maintenance of recent population and economic growth rates. That is, a maintenance of current energy prices, and economic and political conditions including continuing financial support from donor countries for the budget of the State of Palestine.

The Balanced Prosperity scenario is based on a lower population growth, a higher overall economic growth, and an improved political situation resulting in increased international assistance and access to finance for the State of Palestine.

The results presented in this manuscript are, by necessity, aggregated and selective. The primary focus is on the central scenario, which reflects the consequences of Palestine continuing in a "business-as-usual" mode. A brief overview of the implications of applying each of the extreme scenarios is provided for each individual infrastructure sector as well as in the cross-sectoral analysis. The scenarios and strategies were applied to the Gaza and West Bank separately but their results are combined here for brevity. A more extensive version of these results that is disaggregated by region can be found in (Ives et al., 2018).

It should be noted that neither of the socio-economic scenarios explicitly include any large-scale 'en masse' return of Palestinian diaspora, comprises of approximately two million people residing in Jordan, and nearly half a million in either Syria or Lebanon (PCBS, 2010b; Poppert, 2017). The Unbalanced Adversity scenario could be regarded as accommodating a slow rate of diaspora return but a sudden return of a large number of diaspora would represent a much steeper population growth rate than presented. large-scale return of diaspora may not be as dramatic as feared according to Zimmerman et 
al.'s (2006) who have argued that a significant number of the diaspora may already be included in the official PCBS population estimates of Palestine's current population.

\section{Strategies for infrastructure provision}

There are many policies and investments ('levers') decision-makers can employ in Palestine to alter the direction of infrastructure provision. Two key levers in developing and post-conflict countries are the levels of investment in each infrastructure sector, and the ability or ambition of governing bodies to apply these investments to the various sectors. These levers of policy and investment can provide a structure against which the alternative strategies used in this study can be compared (Figure 3).

No single strategy under such a simple framework can adequately describe the wide range of decisions which must be made by government and others. However, in following the Otto et al. (2014) methodology we are not concerned with producing an optimal strategy for Palestine. Instead we are concerned with providing a range of strategies that allow an exploration of the implications of alternative policies that could plausibly be adopted.

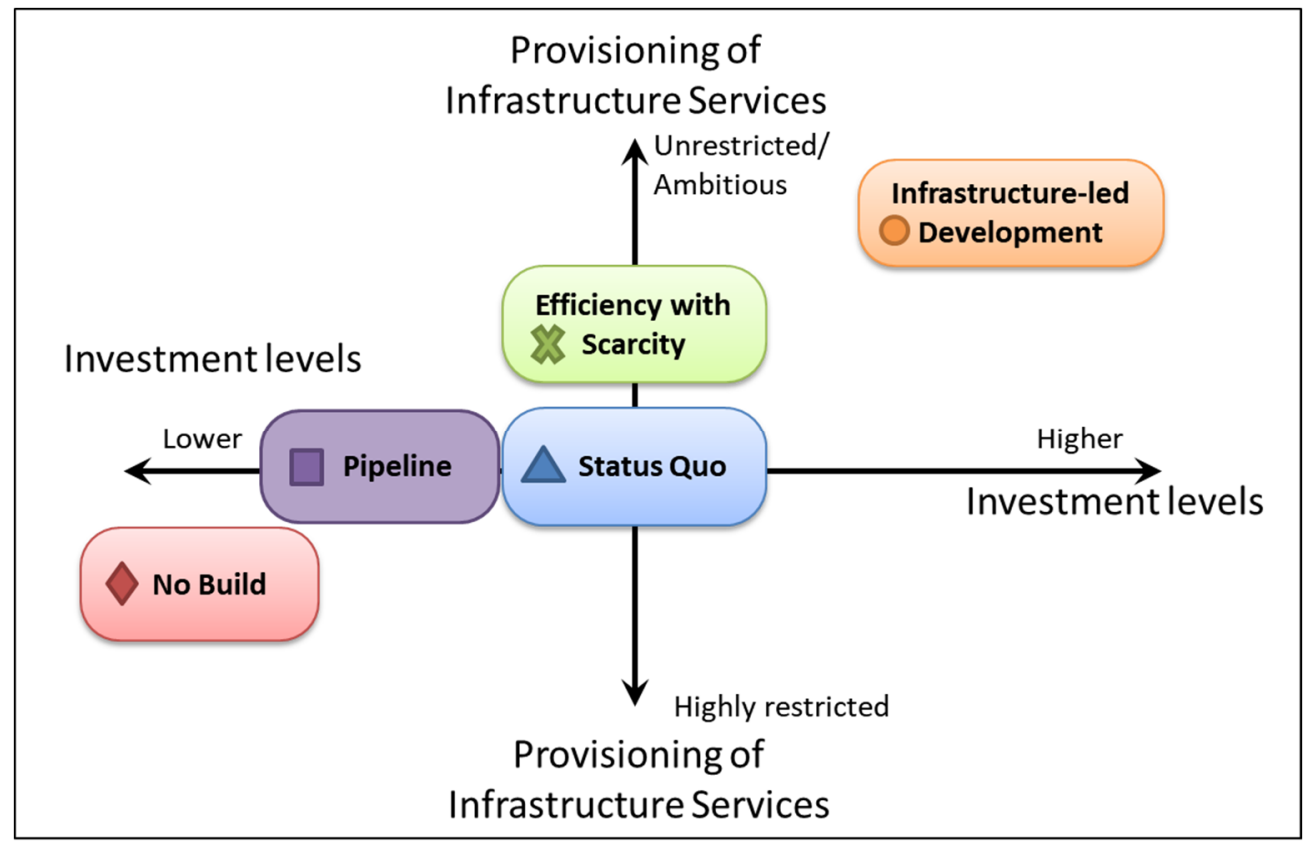

Figure 3: Framework for positioning the selected strategies of infrastructure provision. The symbols shown for each strategy match those used in other graphics provided in this manuscript

\section{No Build (NB)}

With no future investment in infrastructure beyond the 2015 base year, this 'strategy' is a heuristic tool providing a counter-factual to the other more realistic strategies. Infrastructure services will deteriorate through time as demands grow (i.e. socio-economic growth), and as supplies decrease either due to existing capacity expiring or due to changing environmental conditions. Maintenance of existing assets occurs but assets that expire are not replaced.

\section{Pipeline of Planned Infrastructure Investments (Pipeline)}

The Pipeline consists of the list of investments identified by the Palestinian Authority as being under construction or planned for construction over the next few decades (Appendix Table A). This strategy is included as a further heuristic device for assessing the performance of the pipeline over the period of analysis. The pipeline has few projects beyond 2030 , so does not perform well in the long run. Costs for 
this strategy include maintenance on all investments. Note that some pipeline projects are included in the other strategies, depending on the differing levels of investment ambition and technology preference (see Appendix Table A).

\section{Status Quo (SQ)}

This strategy presents a 'baseline' future, giving levels of investment in line with historic levels, so that per capita supplies of infrastructure services are maintained under the Central scenario. Priority is given to the sustainable provision of water, so aquifer abstractions must be reduced to sustainable levels by 2020 even at the cost of increasing energy demands through increased desalination programs.

This strategy includes the most likely projects in the pipeline although their fulfilment may be constrained in line with past achievements. Technological growth is completely exogenous i.e. market driven. Imports will increase for energy and water sectors to fill in any gaps in maintaining per capita infrastructure services not provided by local assets.

\section{Efficiency with Scarcity (ES)}

This strategy is based on the priorities identified in the Envisioning Palestine report (State of Palestine, 2015) to empower Palestine with greater autonomy of resource production, increased efficiency in service delivery and improved waste management. The strategy assumes an improved political environment, and access to the latest materials and technologies. However, there are constraints in terms of investments and the majority of improvements will arise through efficiency measures.

Per capita supplies of infrastructure services are maintained under the Central scenario for this strategy. Any cost savings achieved through efficiency measures or smart infrastructure planning are used to achieve these goals sooner and include more Pipeline projects. Asset types are deliberately chosen to reduce reliance on imports and improving local production of infrastructure services. Demand management options are promoted where applicable, and renewable energy sources are chosen over those dependent on imported fuels.

\section{Infrastructure-led Development (ID)}

This is an aspirational strategy where future service delivery goals are considerably higher than current levels. The aim of this strategy is to reduce infrastructure constraints and unlock economic growth potential, focusing on gains made through economies of scale and exploitation of local comparative advantages such as solar potential and population density. This strategy assumes greater interactions with regional neighbours and the wider global community and donors.

Similar to the ES strategy, the ID strategy is based on the priorities identified in the Envisioning Palestine report (State of Palestine, 2015) but with much greater investment in infrastructure, such that goals for service delivery are met by 2030 - namely, 100 litres per person per day of water, corresponding to the WHO's recommended water requirements for assuring all consumption and hygiene needs (Howard and Bartram 2003); 9,000 kWh per person per annum, corresponding to the next lowest per capita demand of Palestine's neighbours (Egypt - (World Bank, 2014b)); 100\% of solid waste and wastewater treated; and equal levels of lane kilometres per vehicle of roads in Gaza Strip as in West Bank. The infrastructure pipeline is fully implemented in this strategy using the most ambitious timeline. Increases in imports are kept equal or below those of the SQ strategy, and national-scale solutions and economies of scale are sought through building larger assets connected by national networks. Water gained from wastewater reuse and energy from waste is maximised and newer technologies promoted. 


\section{Results from individual sector analyses}

\section{Water}

The Middle East is a semi-arid region characterized by deteriorating water resources and unsustainable development (Bank, 2018; Brown and Crawford, 2009; Kanyoka and Eshtawi, 2012). Accordingly, water supply is one of the most significant and urgent issues to be addressed in Palestine's infrastructure services, particularly in the Gaza Strip (Afifi, 2006; Brown and Crawford, 2009). The need for viable solutions is becoming alarmingly urgent with the added difficulty of the Levant region's vulnerability to climate change and a difficult political climate (Bergaoui et al., 2015; Christensen et al., 2007).

In 2014 the total water supply in Palestine was 342.7 million cubic metres (MCM), obtained from the following sources: pumping from Palestinian wells (72\%), purchased from Israel (Mekorot) (19\%), springs discharge (8\%), desalination (1\%) (PCBS, 2014a; PWA, 2015). Rainfall varies by governorate, with quantities ranging from $700 \mathrm{~mm}$ (Tulkarm) to $200 \mathrm{~mm}$ (Jericho) in 2015, while potential evaporation levels are high, with Jericho recording the highest monthly average of $195 \mathrm{~mm}$ (PCBS, 2015b, e).

Although amounts vary by region, average household monthly water consumption is currently 623 litres per day (PCBS, 2015a), amounting to daily per capita consumption rates of roughly 79 litres/capita/day in both the West Bank and the Gaza Strip (PCBS, 2014b, c), which is below the WHO-recommended levels.

The only natural water resource available in Gaza, the Coastal Aquifer, is being depleted by 100 million cubic meters (MCM) per year more than is sustainable in the long term ${ }^{2}$ (UNRWA, 2012). The aquifer is being impacted by contaminants from seawater intrusion, wastewater, manure and natural occurrence.

Two decades after the Oslo II Interim Accords gave Israel temporary control of most regional water resources, the Palestinian population has doubled, yet extraction levels have remained at around 1995 levels. In addition, Israeli permit regimes in the West Bank restrict the planning and development of Palestinian water, sanitation and hygiene infrastructure (EWASH, 2015). Only about 15 percent of the recharge capacity of the West Bank's water system appears to be available to Palestinians (Haddad, 2009; Isaac et al., 2015), which is well below the levels allocated in the Accords.

Looking to the future in the Central growth scenario (Figure 3) we see increasing difficulties for Palestine with rapidly declining per capita water levels in a No Build environment and even with all projects currently in the Pipeline. In Gaza Strip in particular, there are immediate and ongoing problems of water supply given the reduction in water supplies necessary to restore the Coastal Aquifer Basin and the relentless population growth that continually increases water demands. However improvements are possible when applying more ambitious strategies of infrastructure provision with water consumption being maintained in both the Status Quo (SQ) and Efficiency with Scarcity (ES) strategies and the target of $100 \mathrm{l} / \mathrm{c} / \mathrm{d}$ being achieved in the Infrastructure-led Development (ID) strategy through significant investments, primarily in desalination plants (Figure 4). Even though we have assumed no more abstractions can be made from the West Bank aquifers (UN-ESCWA and BGR, 2013), the West Bank achieves the $100 \mathrm{l} / \mathrm{c} / \mathrm{d}$ target by 2050 with less than half as much new infrastructure as Gaza due to the Gaza aquifer abstractions being reduced to sustainable levels.

\footnotetext{
${ }^{2}$ The annual sustainable yield of the aquifer within the geographical boundary of Gaza is 55 million cubic metres (PWA, 2011).
} 

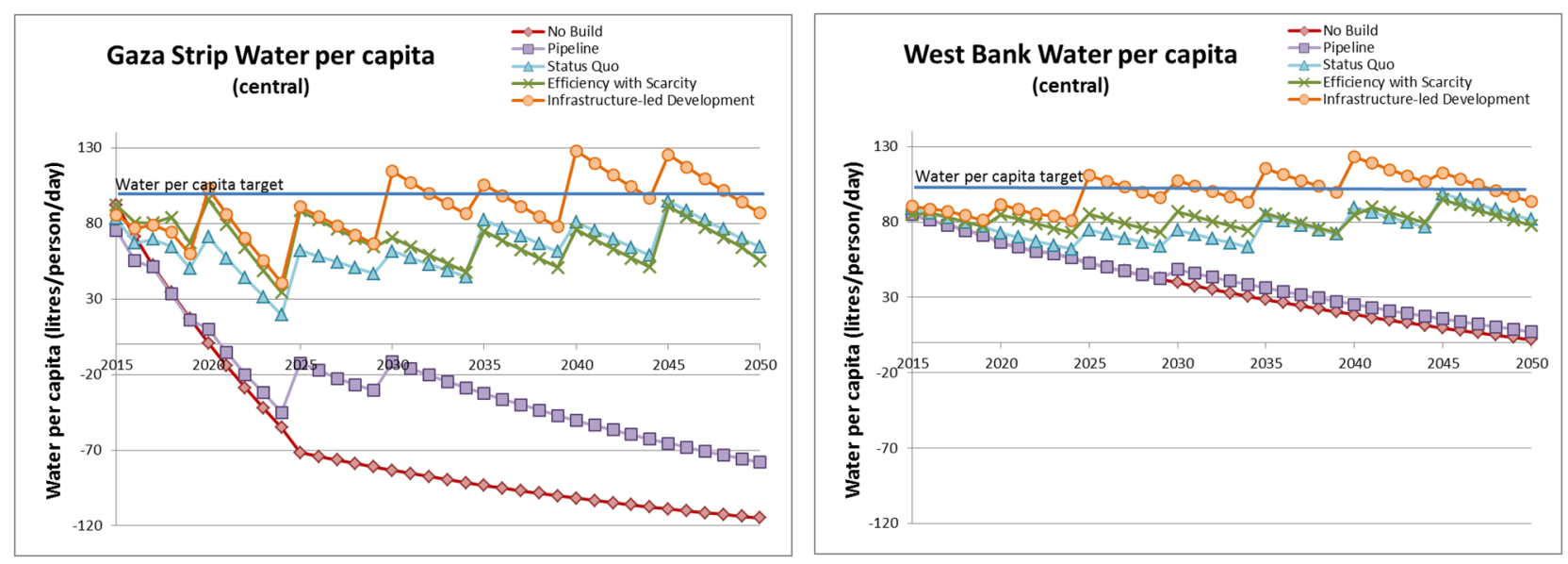

Figure 4: Water supplied per capita (litres/person/day), Gaza Strip (2015-2050, central growth, all strategies)

Assessing the mix of water sources required by each strategy (Figure 5 ), we see that future water supplies are heavily reliant on desalination and an increase in imports at levels that may not be feasible in the current political environment (Office of the Quartet, 2016; PWA, 2011). The ES strategy is able to gain more water from wastewater re-use and hence rely less on imports. Such gains are lost to some degree in the ID strategy due to demands for CCGT energy plants for cooling water putting additional strain on local water sources.

For the Balanced Prosperity (low population growth) scenario the situation improves decidedly under identical investments for each strategy, with water supply per capita in Gaza exceeding the $100 \mathrm{l} / \mathrm{c} / \mathrm{d}$ WHO minimum for the SQ and ES strategies by 2040. For the Unstable Adversity (high population growth) scenario, water supply levels in Gaza fall to less than $30 \mathrm{l} / \mathrm{c} / \mathrm{d}$ by 2050 for the $S Q$ and ES strategies, and so such continued pressures of population growth would require even more investment, up to $60 \%$ more in the $I D$ strategy.

\section{Energy}

Palestine consumed 19.43 TWh $(69,950$ TJ) of energy in 2015 , which can be broken down into the following sources: 11.68 TWh (42,060 TJ) of fossil fuels (bitumen, oils and lubricants, LPG, fuel oil, kerosene, gasoline, diesel), $5.22 \mathrm{TWh}(18,779 \mathrm{TJ})$ of electricity, $1.78 \mathrm{TWh}(6,414 \mathrm{TJ})$ of biomass, and 0.75 TWh (2,670 TJ) of solar PV (PCBS, 2015d).

Energy consumption is led by the transport sector (46\%), followed by households (40\%), commerce and public services (8\%), industry (5\%) and agriculture (1\%) (PCBS, 2015d). The majority of Palestine's primary energy supply is provided by imports (84.8\%), with the remaining energy supplied by solar PV and fuel wood. These latter sources, and a currently unexploited gas field off Gaza's coast, are the only potential sources of local primary energy production. In terms of final energy supply mix these primary sources are 
consumed as $58.1 \%$ fossil fuels (diesel, gasoline, LPG, bitumen and kerosene), $26.1 \%$ imported electricity, and $15.8 \%$ renewables, including solar energy and biomass (PCBS, 2015d).

The UN Millennium Project highlight the availability of energy services as a key factor in achieving Millennium Development Goals and suggest a minimum annual per capita energy requirement of approximately 50 kilograms of oil equivalent $(\mathrm{kgoe})^{3}$, or $580 \mathrm{kWh}$ (Modi et al., 2006) ${ }^{4}$. Despite exceeding this minimum, energy consumption in Palestine remains far below the rising Arab world average of 1,800 kgoe $(20,000 \mathrm{kWh})$. Most energy demand $(75 \%)$ is accounted for by the service and household sectors with little manufacturing activity. Despite high rates of connectivity, reliability of supply is a major issue within Palestine, particularly for Gaza Strip, with daily electricity cuts of up to 18 hours for the majority of Gaza's population and $88.5 \%$ of Gaza businesses having a lack of reliable power (Office of the Quartet, 2016).

Projecting energy demands into the future produces estimates of between 41,000 and $67,000 \mathrm{GWh}$ of energy demanded by 2050 in Palestine if current per capita energy levels are maintained. These are the levels of demand that must be met by the $S Q$ and $E S$ strategies in our analysis. For the more ambitious ID strategy where per capita energy levels are increased to $9,000 \mathrm{kWh} /$ person these demands grow to between 80,000 and 140,000 GWh by 2050 .

The performance of each strategy in meeting these demands is shown in Figure 6 for the Central socioeconomic scenario. Achieving the goal of just maintaining current per capita demands will require a doubling of energy supplies by 2050 in the SQ and ES strategies. The Pipeline projects are able to meet these demands to 2040 in Gaza Strip, providing that the most ambitious Gas 4 Gaza capacity is installed, but only meet demands up to 2030 in the West Bank despite the construction of two large CCGT power stations.
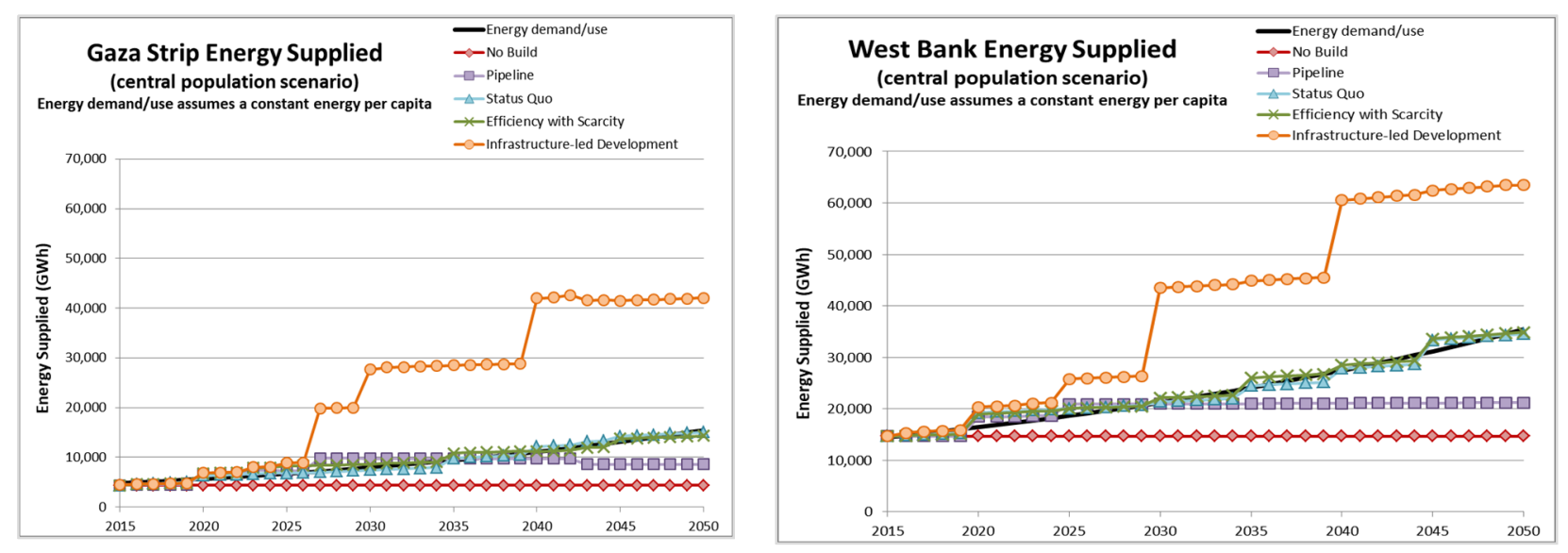

Figure 6: Energy supply (GWh) for Gaza Strip and West Bank (2015-2050, central growth, all strategies). The step increases in capacity coincide with investments in either renewables or CCGT, depending on the strategy.

Figure 7 shows the energy mix associated with each strategy in the Central scenario. The ES strategy is able to maintain the same demand per capita to 2050 with a lower reliance on imported electricity and

\footnotetext{
${ }^{3}$ Kilograms of oil equivalent, abbreviated as kgoe, is a normalised unit of energy used to convert energy supplied by a variety of sources into equivalent units. It is assigned a standardised net calorific value of 41,868 kilojoules $/ \mathrm{kg}$. $1 \mathrm{kgoe}=11.63 \mathrm{kWh}$

${ }^{4}$ No equivalent requirement has been provided within the new Sustainable Development Goals framework
} 
higher levels of renewables than the SQ. The Palestinian Authority has set a target of $130 \mathrm{MW}$ of renewable energy by 2020 (World Bank, 2017). However, this goal is only met by the ID strategy and not until 2025 employing all renewable projects in the current infrastructure pipeline.

For the Balanced Prosperity (low population growth) scenario, assuming the same level of infrastructure investments for each strategy, the per capita targets are exceeded for the ID strategy in 2030 for both Gaza and West Bank, and there a fewer investments needed beyond these dates to maintain that level. Conversely, for the Unstable Adversity (high population growth) scenario, the same level of investment provides around 7,000 kWh per capita rather than reaching the 9,000 kWh target. To achieve that target by 2050 requires the provision of an extra 12,000 GWh in Gaza, and 19,000 GWh in West Bank, requiring significantly higher investments as well as more land and water than might be able available under to the Palestinians under such a difficult political scenario.
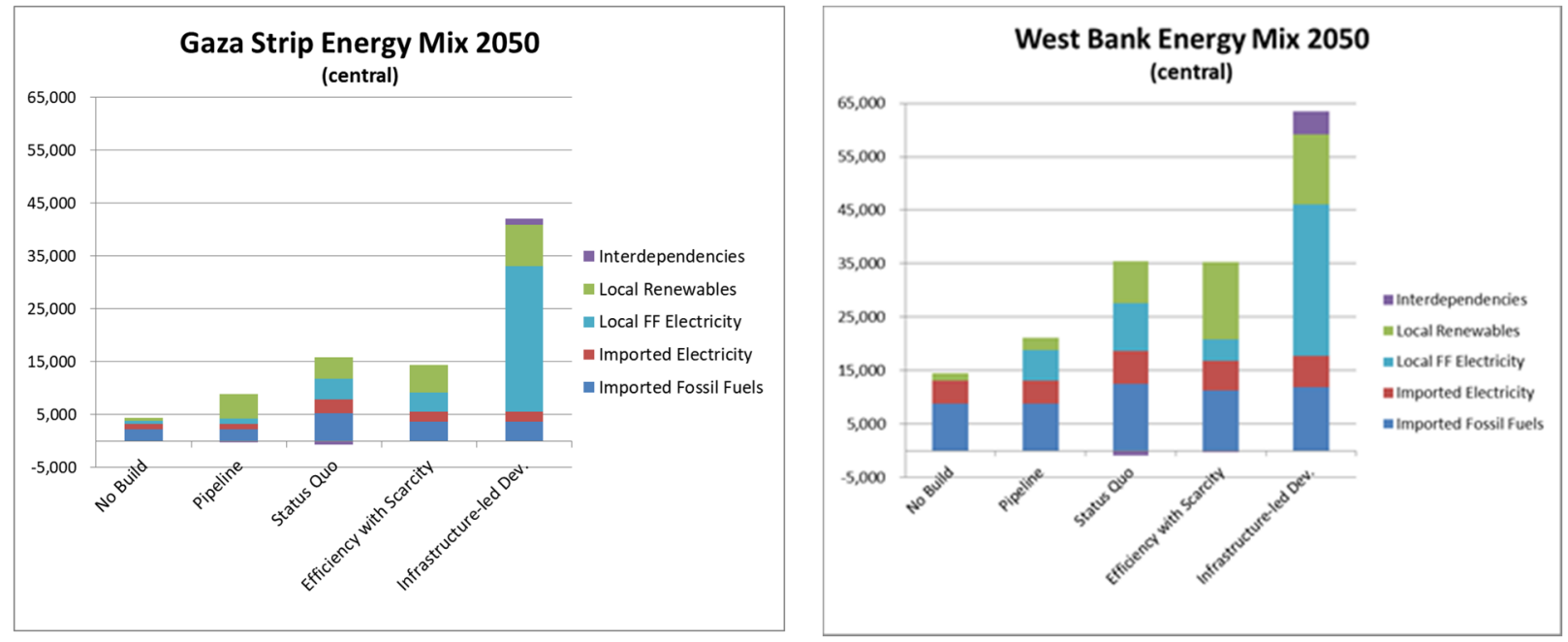

Figure 7: Energy generation mix (GWh), for Gaza and West Bank in 2050 (central scenario)

\section{Transport}

Transport infrastructure in Palestine is currently all road-based and provides mobility and access to economic opportunities within both Palestine and Israel. However, tight security measures restricting movement on major routes affects traffic flows, resulting in transportation delays that affect the competitiveness of economic activity in Palestine (Isaac et al., 2015). A recent report estimates the annual cost to Palestinians of the main movement and access restrictions to be about USD\$185 million per year due to extra time and mileage (Isaac et al., 2015). Transportation infrastructure in Gaza (e.g. roads, bridges) has also been repeatedly damaged during conflicts with Israel (OCHA, 2016).

Palestine had around 63 vehicles per 1000 people in 2014 (PCBS, 2014e) which is relatively low compared to other nations and neighbouring countries (generally above 300 vehicles per 1000 people) (NationMaster, 2014). The total paved road network length for the West Bank and Gaza is 3,544 kilometres, with a further 445 kilometres of unpaved roads in the West Bank (PCBS, 2014d).

Future road network construction requirements in Palestine is estimated by evaluating increases in passenger car unit demands into the future to maintain existing transport networks (paved roads), accounting for any uneven socio-economic growth effects on links between governorates. Data on lane kilometres of paved road by governorate (PCBS, 2015h) and roads connecting each governorate (Ministry of Local Government, 2016) was projected into the future to provide estimates of possible construction and maintenance requirements for each of the strategies. 
The results from these strategies are presented in Figure 8 for Gaza Strip and West Bank. The $N B$ and Pipeline strategies both include no increase in road kilometres as no information could be found around any road projects in the infrastructure pipeline. The $S Q$ and $E S$ strategies both use the current rate of construction which is an approximate increase in new road kilometres per year of $0.7 \%$ (PCBS, 2015h, 2016)).

Without any information on congestion the $I D$ strategy aims to provide a more even distribution of lane kilometre between Gaza Strip and the West Bank. For the West Bank the rate of new lane construction is set at current construction rates. Given that West Bank already has an extensive road network and limited evidence of serious congestion that is not related to security access points, the current rate of construction appears to be adequate. For Gaza Strip the construction is set to $150 \%$ of the current population growth (3.4\%) in an attempt to bring the Gaza Strip more in line with the West Bank by 2050 (requiring almost six times the current estimated construction rate).
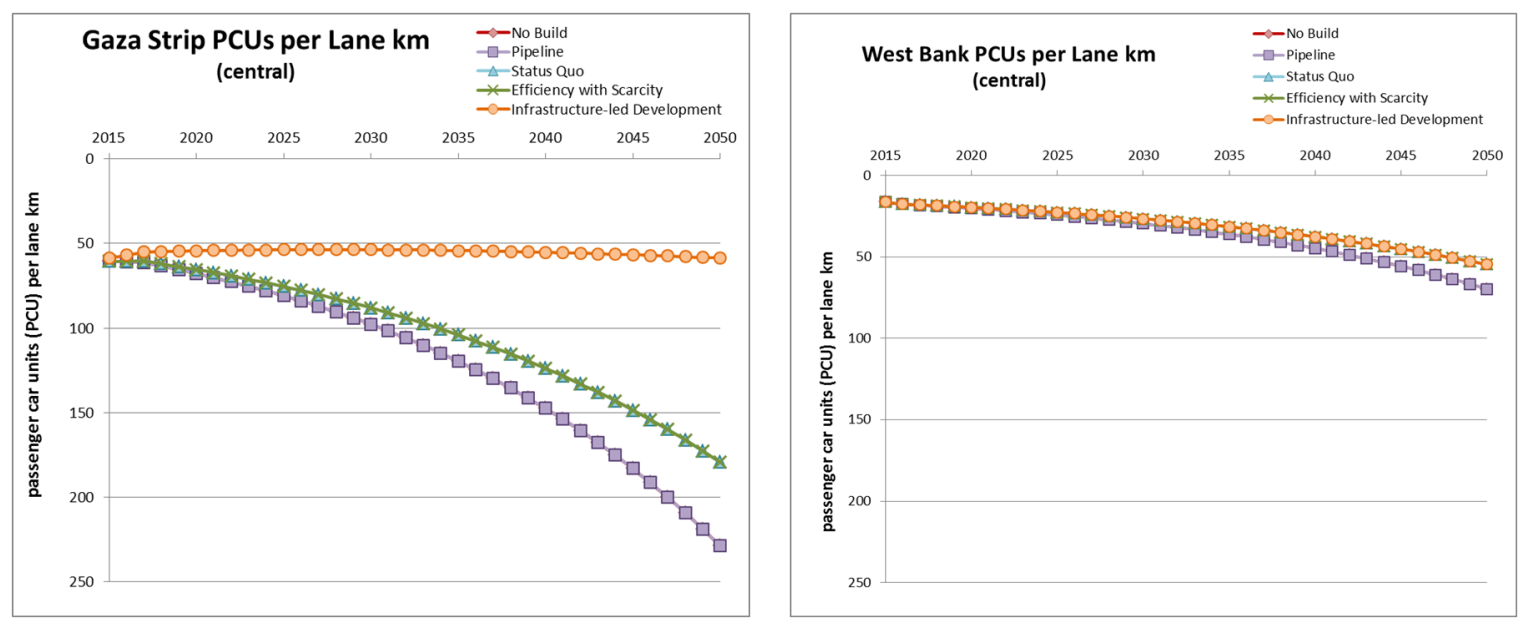

Figure 8: Estimates of passenger car units per road kilometre for Gaza and the West Bank 2015-2050 (central growth, all strategies). Note that the No Build and Pipeline strategies have identical results, as do the Status Quo and Efficiency with Scarcity strategies.

For the Balanced Prosperity (low population growth) scenario we see around a $13 \%$ decrease in passenger car units per road kilometre (PCU/ km) across all of Palestine given the same investments. However, this decrease does little to improve the situation in Gaza for all strategies except the ID strategy. For the Unbalanced Adversity scenario, we see an $18 \%$ increase in PCU/km across all of Palestine with the same investments requiring the construction rate to increase nine fold over current levels to achieve the ID goals.

To examine the implication of the Palestinian Authority's proposed plans for airports in the West Bank and Gaza and a larger seaport in Gaza these investments were included in the ID strategy. Costs for each will depend on their capacity which has yet to be defined. A combined airport and seaport island terminal off the Gaza coastline has been proposed at an estimated cost of USD\$5 billion. This man-made island would include a single runway, cargo port, gas-fired power generator and desalination plant (Sanchez, 2017).

\section{Wastewater}

Given the extreme water stress faced by Palestine and water consumption rates below recommended WHO levels (UN Human Rights et al., 2010) the treatment and reuse of collected wastewater is vitally important in the Palestinian territories (Eting, 2015). Wastewater infrastructure in the Palestinian territories has however been largely neglected since 1967 with capital investments focused primarily on 
the provision of drinking water (PWA, 2012). While connection to wastewater collection networks is available to the majority of localities in the Gaza Strip, it is often old and poorly maintained, and is only limited to a few municipalities in much of the West Bank, mainly the large cities and refugee camps (PCBS, 2015c; PWA, 2012). The rest of the Palestinian population, amounting to over 1.5 million people (PCBS, 2010a), including $94.5 \%$ of the West Bank's rural residents, rely on porous and tight cesspits (in $59 \%$ and $22 \%$ of localities, respectively), exposed networks (2.5\%) and channels (4\%) for wastewater disposal (PCBS, 2015f).

In 2015, over 114 million $\mathrm{m}^{3}$ (MCM) of wastewater were produced in the Palestinian territories, with 66 MCM produced in the West Bank, including water discharged by settlements and industrial zones, and around $48 \mathrm{MCM}$ produced in Gaza. In the West Bank, around $41 \mathrm{MCM}$ of wastewater is dumped annually into cesspits, and around $15 \mathrm{MCM}$ is dumped straight into wadis (streams) untreated, then withdrawn again and treated in Israeli wastewater treatment plants (WWTPs) inside the green line, to be reused by Israel. A further $6 \mathrm{MCM}$ is dumped annually into local streams and not subsequently treated (Isaac and Rishmawi, 2015). In the Gaza Strip, around 37 MCM of the 41 MCM wastewater collected by sewage networks in 2015 were partially treated and discharged into the environment. Both partially treated and untreated wastewater is also discharged into open areas including wadis such as Wadi Gaza and the Mediterranean Sea with many discharge points registered along the shoreline in the Gaza Strip (Isaac and Rishmawi, 2015).

How each of the strategies is expected to affect future wastewater treatment is shown in Figure 9. Included in the Pipeline are three proposed new treatment plants in Gaza Strip, with the Central WWTP encompassing a design capacity of $65 \mathrm{MCM}$ assumed to be available from 2030 onwards. This latter WWTP has a significant effect on the treatment capacity in Gaza Strip allowing enough treatment capacity for all the extra wastewater expected in the central population growth scenario to 2040.
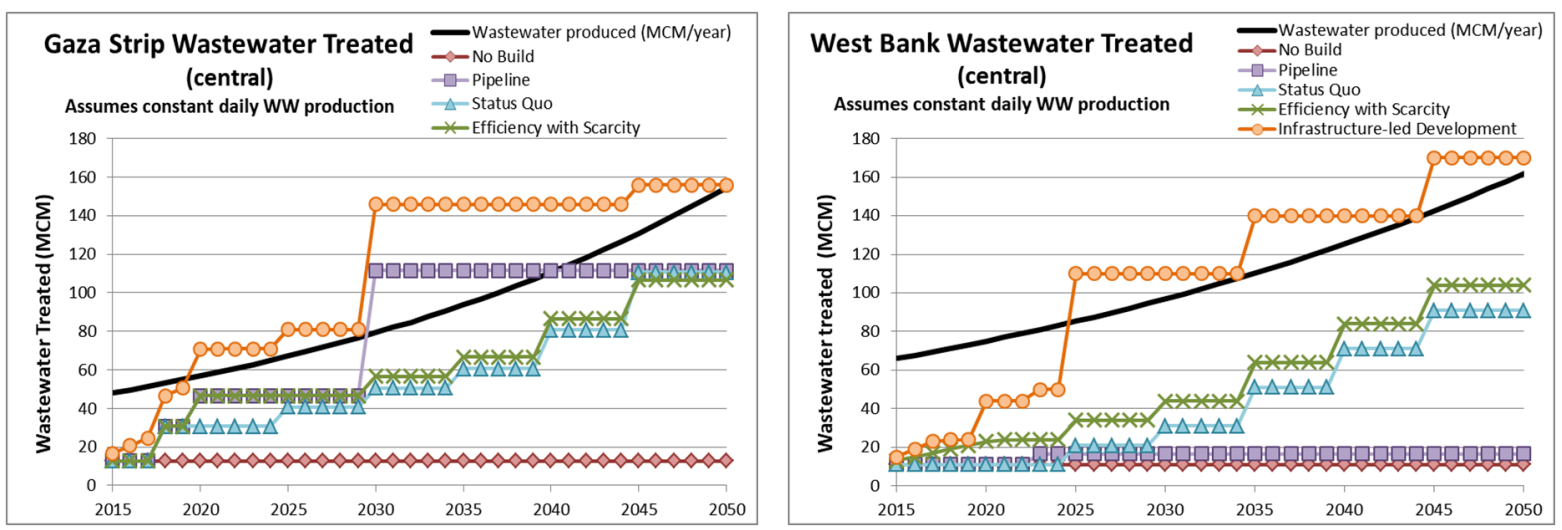

Figure 9: Wastewater treated (MCM), Gaza Strip and West Bank, 2015-2050 (central growth, all strategies)

The pipeline project proposed for the West Bank, however, only adds an additional $6 \mathrm{MCM}$ treatment capacity to a system which is already failing to meet demand. In order to meet future demand for treatment capacity, WWTPs which are currently working far below capacity must be rehabilitated, and additional WWTP treatment capacity added to the system.

For the Balanced Prosperity scenario, all strategies achieve the goal of treating all wastewater by 2050 in Gaza, but there is still a deficit in West Bank of $20 \mathrm{MCM}$ per year for ES, and $32 \mathrm{MCM}$ for SQ. For the Unbalanced Adversity scenario, the deficits in the West Bank become 109 and 122 MCM respectively, with a deficit of $53 \mathrm{MCM}$ for the ID strategy, assuming the same construction profile in West Bank. In 
Gaza, the Unbalanced Adversity scenario results in a treatment capacity shortfall of $19 \mathrm{MCM}$ for $I D, 58$ MCM for ES, and 64 MCM per year for SQ.

\section{Solid Waste}

Solid waste management efforts in Gaza and the West Bank are unsatisfactory due to political and institutional obstacles that limit their effectiveness (D-Waste, 2014). Unregulated dumping of most waste, including medical and hazardous substances, is widespread, and landfill and transfer sites do not yet have the capacity to manage the quantities of waste generated in the territories. The resulting contamination of the environment has significant health consequences for the Palestinian population (Isaac et al., 2011).

Approximately 1.39 million tons of municipal waste is generated per year in Palestine, amounting to about $0.94 \mathrm{~kg}$ per capita per day with a range from 0.35 to $2.05 \mathrm{~kg}$. Persons in urban areas produce higher amounts of waste, with many places in Palestine on the low end of per capita waste production compared to counterparts in both the Middle East and the wider international community. According to UNEP, Israeli settlers in the West Bank generate approximately $2 \mathrm{~kg}$ of solid waste per capita per day, amounting to approximately 15 thousand tons of additional waste per year, the large majority of which is also disposed of in random dumpsites in the West Bank (D-Waste, 2014; UNEP, 2003).

While overall municipal waste has increased by about $4 \%$ each year, $3 \%$ of this is due to population growth, with the remaining $1 \%$ the result of increased per capita waste arisings. The dominant method of municipal waste management in Palestine is dumping in open, uncontrolled, and unmonitored sites $(67 \%)$, while much of the rest is landfilled (33\%), and marginal amounts (less than $0.5 \%$ ) are composted and recycled, usually by private firms (D-Waste, 2014). Given projected 2015 waste generation levels, this means that over a million tons is openly dumped, with only half a million tons landfilled.

Overall, municipal solid waste collection levels are at $93 \%$ in urban areas and $88 \%$ in rural areas (D-Waste, 2014), although collection frequency is often inadequate, leading to accumulation of waste in certain areas (Isaac et al., 2011). There are currently four landfill sites in the West Bank (D-Waste, 2014) although recent reports suggest that only two of these are currently operational (Hattem, 2014). Three landfill sites currently operate in the Gaza Strip (El Baba et al., 2015), one of which is for hazardous materials and not currently operational.

The results of the modelled strategies of future investments in municipal waste treatment capacity are shown in Figure 10. There is one new 300,000 tons per year municipal landfill site in the Pipeline in Gaza Strip that is assumed to be active by 2020 . Despite its size this landfill has only limited effect on the treatment capacity in Gaza Strip as services are already well below requirements. All strategies therefore require significant investments to treat the amounts generated in the central population growth scenario. If this large landfill is not constructed, as shown in the $S Q$ strategy, treatment capacity essentially declines to zero by 2025. We assume for simplicity that all landfill facilities will work at design capacity and have a 20-year lifetime unless otherwise stated. 

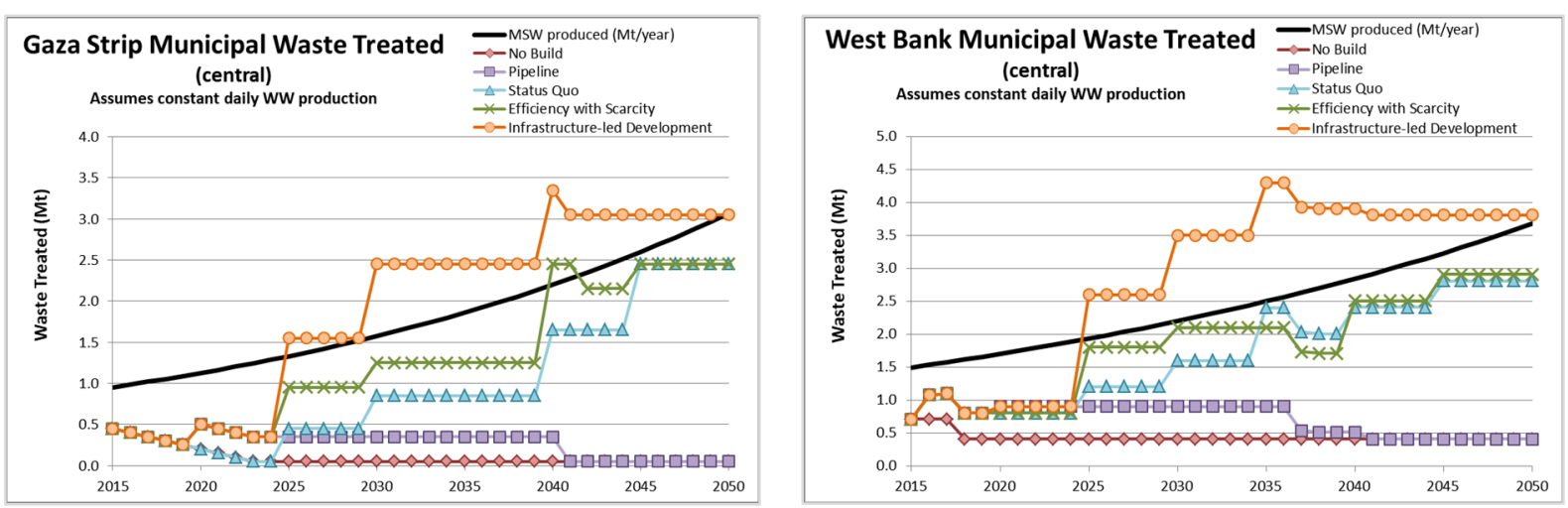

Figure 10: Municipal waste treated (Mt), Gaza Strip and West Bank 2015-2050 (central growth, all strategies)

Planned investment in solid waste management in West Bank is more in line with future demand requirements but additional investment is each strategy to maintain current levels of municipal waste treated ( $S Q$ and $E S$ ) and a 3-fold increase in investment is required by 2030 to treat all waste (ID strategy). Both the $E S$ and $I D$ strategies make use of energy from waste technologies to treat waste. This leads to significantly higher treatment costs but also allows for the generation of an additional 1,100 and 2,500 GWh of energy in the ES and ID strategies respectively, with the latter amounting for around $2.5 \%$ of total energy demand by 2050. Even higher levels of energy from waste are viable under certain assumptions of the wastes' average calorific value.

For the Balanced Prosperity (low population growth) scenario, all strategies meet the additional demand by 2035 in West Bank and 2045 in Gaza. For the Unstable Adversity (high population growth) scenario, each strategy experiences a shortfall in treatment capacity by 2050, with a deficit in Gaza of $1.2 \mathrm{Mt}$ for SQ and $E S$, and $0.5 \mathrm{Mt}$ for $I D$, and $2 \mathrm{Mt}$ for $S Q$ and $E S$, and $1 \mathrm{Mt}$ for $I D$ in West Bank, assuming the same construction profiles as used for the central scenarios.

\section{Results from the cross-sectoral analysis}

The preceding sections presented single sector analyses of current and future capacity and demands for five main infrastructure systems in Palestine, and where data have permitted, an analysis of the performance of a set of pre-defined strategies. Until now the costs associated with these strategies has not been presented. Accordingly, Figure 11 shows the estimated cumulative costs in 2050 for each of the strategies by sector. These estimated costs include capital expenditure on new infrastructure as well as operational costs and are based on published records and pipeline project costs where data was available (or estimated from the U.K. Institution of Civil Engineering infrastructure cost database (ICE, 2016) and other sources). Not all operating costs could be estimated and future costs are presented in current US dollars with no discount rate applied.

When compared to the current Pipeline the proposed strategies appear costly but not infeasible within the moderate population increases of the central strategy. One striking feature of this graphic is the relative cost of providing adequate water supply to the Palestinian population. Much of this cost is due to the required investments in desalination which is becoming less expensive, although not to a point that will bring water supply costs on level with other sectors (Ghaffour et al., 2013). Another noteworthy result presented in the Infrastructure-led Development strategy is that water supplies can be increased at an advantageous relative cost through investments in the energy and waste sectors. 


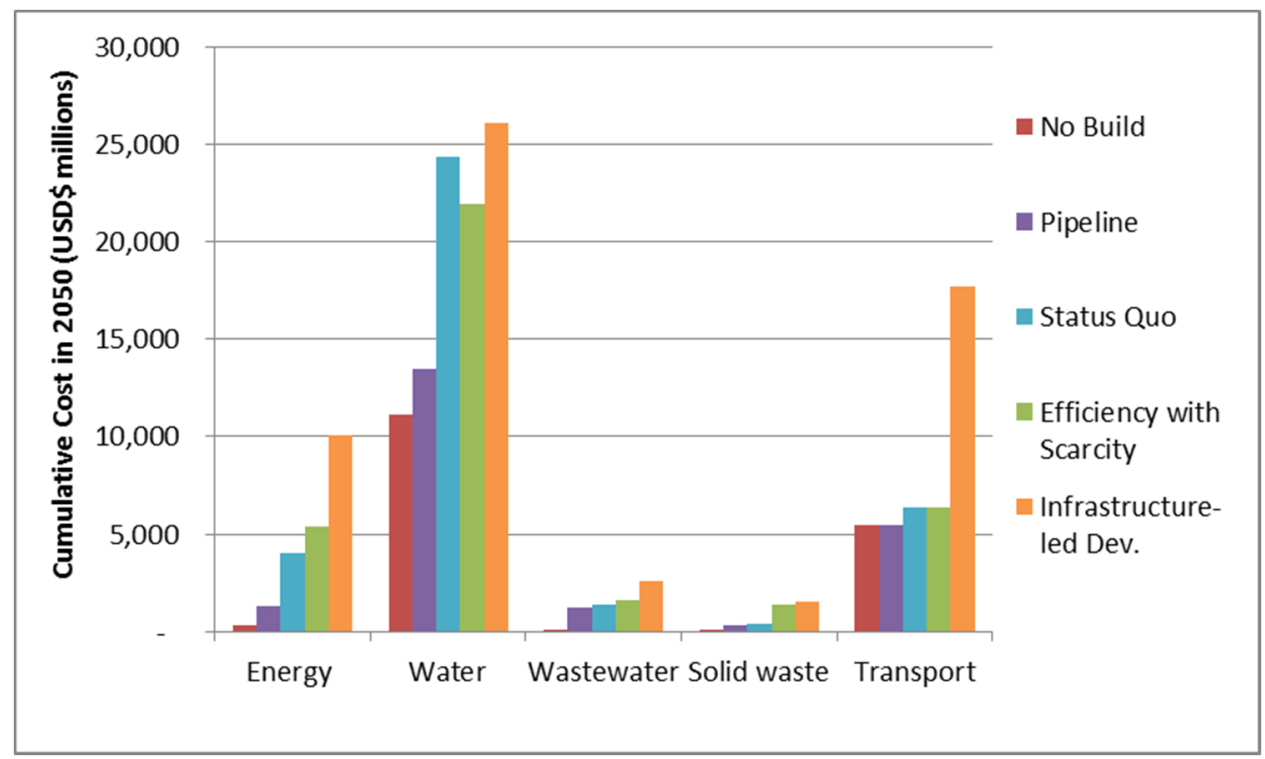

Figure 11: A comparison of relative cumulative costs by sector by strategy

Not all interdependencies between infrastructure sectors however are positive, so planners would be wise to consider the interdependencies that create demands across sectors. The tight coupling of many of Palestine's infrastructure systems, particularly energy and water, require solutions that are cognisant of such interdependencies (Hall et al., 2016b). A more detailed examination of the interdependencies in the Infrastructure-led Development strategy shows that up to half of energy demand (9,000 GWh) will come from transport, with the water and wastewater sectors requiring a further 2,300 GWh. Fortunately, around $6,000 \mathrm{GWh}$ of this energy demand can potentially be gained back from solid waste and wastewater to energy programs. Similarly, energy systems will require an additional $30 \mathrm{MCM}$ of water for cooling but up to $145 \mathrm{MCM}$ could be gained back through wastewater reuse programs.

The water-energy nexus in Palestine's will need careful attention in their immediate pipeline plans. The proposed $\$ 500$ million desalination plant in Gaza, will require an additional supply of $25 \mathrm{MW}$ of installed energy capacity if it is not to impact already limited supplies for local residents (PWA, 2015). Similarly, the proposed thermoelectric power generation in the Jenin and Hebron must be planned with one eye on the potential impacts on dwindling local water supplies. Although such water demands are not entirely consumptive, assessing the technology and location of any power station requires due diligence regarding the local and system-wide capabilities to deliver the necessary cooling water over the plant's lifetime (van Vliet et al., 2013).

One opportunity for recovering water is through reuse of wastewater, augmenting supplies for other economic sectors, such as agriculture, or for potable water production. The recycling and reuse of waste is not only confined to wastewater but can also be implemented in the solid waste sector. This step towards a 'circular economy' will not only reduce waste arisings but also provides materials for the derivation of energy from waste (Diaz, 2017).

Similar considerations must also be made for any planned ports. Transport provides services that span across all sectors through mobility to the personnel and goods required to operate facilities. The expansive and pervasive nature of transport means that minor changes in its function and operation can have broad and unexpected consequences in different sectors, as suggested by the estimated USD\$185 million per year in costs imposed by Israel on Palestinians through security-based mobility restrictions (Isaac et al., 2015). 
The decision to adopt any infrastructure provision strategy will ultimately depend on multiple factors and criteria. To understand the trade-offs inherent in this decision-making process we provide here the concept of service delivered as one potential cross-sectoral measure of infrastructure performance. The service delivered is a measure of the services delivered in each sector normalised across the lowest and highest values of the indicator in all scenarios. The units of service delivered are different for each sector, for the energy sector it is measured in $\mathrm{kWh} /$ person; for water supply we use litres/person/day; for transport we have passenger car units per lane kilometre; and for wastewater and solid waste we use \% of waste treated. Comparing these normalised measures relative to the cumulative costs enables an exploration of the many cross-sectoral trade-offs confronting Palestinian decision makers. Figure 12 shows the cross-sectoral cumulative costs for each strategy against the average percentage change in service delivery from 2015 to 2050 . The vertical bars attached to the points associated with the ambitious strategies show estimates for the range of costs associated with the Balanced Prosperity and Unbalanced Adversity scenarios.

The least cost strategy, No Build, unsurprisingly shows the lowest performance in terms of average services, with a net negative average service delivery across all sectors. All other strategies result in a net positive average service delivery. For all strategies, there is a general positive correlation between the increased cumulative costs of a strategy and the benefits yielded through the average percentage change in service delivery. Despite the Pipeline resulting in negative service delivery at 2050 (with respect to 2015 values) this strategy have a net positive impact.

Both the Status Quo and Efficiency with Scarcity strategies are the closest to each other in terms of performance. The Efficiency with Scarcity strategy appears capable of achieving the additional benefits associated with this strategy at little additional cost over the Status Quo strategy. Also of note is that the Efficiency with Scarcity strategy has a slightly smaller cost spread than the Status Quo, suggesting that it entails less vulnerability to socio-economic uncertainty. Deciding between these strategies would require the consideration of many additional dimensions not calculated in this analysis, although some are implicit in their design, e.g. the Efficiency with Scarcity strategy comes with additional benefit of increased security of supply through reduced reliance on imports.

By concentrating on maximising the benefits from interdependencies and economies of scale, the Infrastructure-led Development strategy is able to achieve higher infrastructure service delivery at a lower per unit cost. However, this strategy may prove prohibitive in practice. Establishing hard constraints (in terms of budget, or another performance metric) can thus help to inform the decision-making process by reducing the overall strategy space under investigation - revealing those strategic approaches and specific investment decisions that are most cost effective given budgetary constraints. 


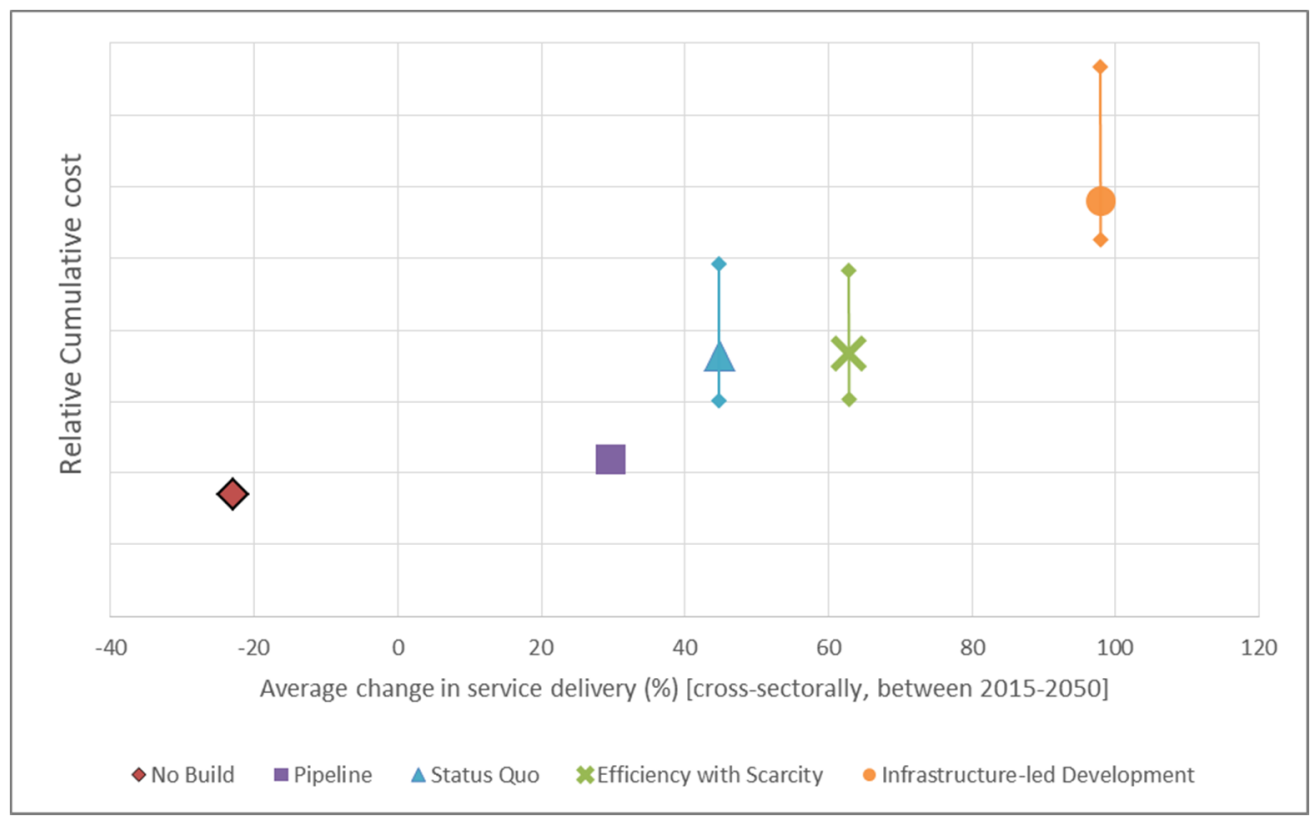

Figure 12: Relative cumulative cost plotted against the mean average percentage change in service delivery (2015-2050) for each of the strategies in the central population scenario. The symbols shown for each strategy match those used in other graphics provided in this manuscript. The bars attached to the right-most strategies show an estimated range of costs for these strategies from the lower demand Unbalanced Adversity scenario to the higher demand Balanced Prosperity scenario.

It is worthy of note that the bands of uncertainty (vertical bars in Figure 11) produced by applying the Unbalanced Adversity and Balanced Prosperity scenarios, do not overlap between the Status Quo and the Infrastructure-led Development strategy. This suggests firstly that the risk from uncertainty represented by alternative socio-economic scenarios is reasonably well constrained, and secondly that the bounds of uncertainty are not so great as to prevent a clear comparison of relative costs for these strategies.

\section{Discussion}

Palestine is currently experiencing deficiencies in the provision of infrastructure services across all sectors assessed in this study. Fortunately a number of major infrastructure projects in the pipeline will deliver improved infrastructure services to the people of Palestine in the coming years. Such measures appear to be well prioritised in water and energy, with emphasis appropriately given to the acute crisis in the Gaza Strip.

The government of Israel has recently announced increases in supplies of water and electricity to this area (Office of the Quartet, 2016). Unfortunately, with current socio-economic trends and the spectre of climate change such measures will soon fall short of meeting the most basic demands in the near future, even under a pessimistic scenario of low socio-economic growth. In fact, the analysis presented here suggests that Gaza will require at least twice as much investment in water infrastructure than is currently in the pipeline over the coming decade if they are to meet World Health Organisation levels of water availability.

Wastewater re-use has been identified in this study as a grossly underutilised resource in Palestine that can help alleviate such water shortages. Current levels of reuse are quite low ( $<20 \%$ in total), with the majority of wastewater pumped to cesspits or discharged mostly untreated into the sea, rivers, and wadis (streams) creating further problems for water supplies and human health. This analysis suggests a gain of up to $145 \mathrm{MCM}$ through wastewater reuse programs in a central socio-economic growth scenario. 
Underpinning all of these problems in water management are inadequacies in the energy sector, which restricts the capacity of water transfer, water treatment and wastewater management facilities. These energy deficiencies also impact on businesses and households. While the majority of houses have access to power most of Gaza's households receive only 6 to 8 hours of electricity per day. This shortage has a number of causes, including insufficient imports from Israel and Egypt, and the Gaza Power Plant only producing at half its full capacity.

Some relief is provided for hospitals, residents and hotels that have access to solar for electricity and solar heating for water heating needs. Renewable sources of energy can thus provide some supplementary supply, but land availability and reliability of the distribution grid have hampered efforts beyond smallscale local energy generation. Thermoelectric energy sources such as Combine Cycle Gas Turbines (CCGT) may also provide reliable and efficient sources of electricity, but could prove problematic in their demand for imported fuels and cooling water in the West Bank. Add to this the fact that even significant investments, such as the Hebron CCGT and Jenin CCGT plants in the West Bank, will only maintain current per capita energy above the current levels for a decade. In Gaza the current pipeline projects, including the Gas 4 Gaza connection and the Gaza Power Plant upgrade to $540 \mathrm{MW}$, could maintain current per capita energy levels (approx. 2,500 kWh/person) beyond 2040. However, if the Gaza Power Plant is only upgraded to $140 \mathrm{MW}$ the current low levels of electricity provision will resume within a decade.

Good resource recovery has the potential to provide some respite in the form of energy from waste. As shown in the above analysis, a further 6,000 GWh of energy can be gained from solid waste and wastewater to energy programs in the central socio-economic scenario. However, despite high waste collection rates in urban environments, the opportunities to utilise this resource are being lost due to illegal dumping and a lack of waste recovery facilities. Some facilities exist for recycling materials and it is estimated that around $44 \%$ of solid waste is treated using sanitary landfills (D-Waste, 2014). Plans are underway for two new sanitary landfills, one in the West Bank and one in Gaza Strip, however these will only serve to replace facilities that will soon close. The percentage of waste treated is therefore expected to decline if additional waste treatment facilities are not commissioned. With such large amounts of waste untreated, coupled with the number of sites not being controlled in terms of leachate (D-Waste, 2014), serious concerns exist around future impacts to scarce water resources, particularly in the Gaza Strip.

The lower levels of infrastructure services in Palestine have led to the current difficult conditions. However, one advantage Palestine has is its potential to take advantage of new technology and a systembased approach to "leapfrog" to more efficient and resilient infrastructure systems. Renewable energy sources could provide new and affordable sources of primary energy production, reducing dependence on imports that drain national accounts (World Bank, 2017). Improvements in water security can be gained through desalination technologies and through capitalising on positive interdependencies.

The tight coupling of many of Palestine's infrastructure systems, particularly energy and water, and energy and transport, require solutions that are cognisant of these interdependencies. The most striking feature of this study being the relative cost of providing adequate water supply to the Palestinian population compared to that of other sectors. Gains are clear if the energy and waste sectors are employed to augment water supplies at advantages relative costs. However, given the multitude of government, private and donor community actors involved in each of these infrastructure sectors, an integrated and well-coordinated management approach with complete transparency in the decisionmaking process will be essential.

A key limitation of the approach here in this study is the reliance on large amounts of up-to-date information. Limitations in this data introduce uncertainty in the analysis, which should be considered when judging the validity of the insights and conclusions presented here. There are also limitations in the 
sophistication of the underlying models and the strategies that have been developed for this analysis. These strategies presented should be considered only as a start to a much more in-depth evaluation of systems-based infrastructure strategies for the future of Palestine.

There is always scope to develop further analyses, such as that presented here, through increasing the sophistication of the underlying models and developing and testing more infrastructure strategies. Future research could also include developing more infrastructure-service related indicators that link to a vision for Palestine's future (State of Palestine, 2015) as well as the UN's Sustainable Development Goals. Developing such capabilities will enable system-wide evidence-based infrastructure planning to coordinate, prioritise and monitor future delivery of infrastructure services. Imbedding individual projects in a holistic national plan will provide confidence in institutional capacity and a consistency in decisionmaking that will attract further donor funding and much needed private investment.

\section{Conclusions}

Whilst there have been many studies of infrastructure requirements in the occupied Palestinian territories, none have sought to take a system-of-systems approach to energy, transport, water, wastewater and solid waste. By employing this approach this analysis has exposed important interdependencies and synergies between these sectors. Moreover, by using scenarios to explore uncertainties in socio-economic drivers, we have been able to place some bounds on the scale of such future uncertainties. We have also demonstrated how quickly failure to adapt to such changing circumstances can lead to a rapid deterioration in service provisions for the Palestinian people.

We have deliberately avoided discussion of the political and security situation in the occupied Palestinian territories, and interactions between the Government of Palestine and its neighbours. We recognise that infrastructure provision has an inevitable political dimension. Whilst deliberately not commenting on this dimension, we hope that by providing evidence and a quantified analysis of trade-offs we will be able to inform the difficult choices that need to be made by those governing the state.

Choices about infrastructure provision need to be based upon local context. Thus great care must be taken when transferring methodology from one country to another. Nonetheless, in the paper we have taken a methodology that was originally developed and applied in the UK and successfully adapted it to a contrasting context, demonstrating the potential of this methodology for a diverse range of national contexts worldwide.

\section{Acknowledgements}

This research was funded by the U.K. Engineering and Physical Sciences Research Council (EPSRC) under Grant EP/101344X/1 with in-kind support from the United Nations Office for Project Services.

We would also like to acknowledge the careful consideration by the anonymous journal reviewers of this manuscript, which has been greatly enhanced by their contributions 


\section{Appendix}

Table A: Planned infrastructure 'pipeline' projects and the strategies that include these investments $(\mathrm{PI}=$ Infrastructure

Pipeline, SQ = Status Quo, ES = Efficiency with Scarcity, ID = Infrastructure-led Development). Based on the information gathered by UNOPS Jerusalem Office and Centre of Excellence for Project Management and Infrastructure from various sources including State of Palestine, PCBS, PWA, PEA, Office of the Quartet, and the Joint Service Council for Solid Waste Management

\begin{tabular}{|c|c|c|c|c|c|}
\hline Project type & Project name & Impact & Completion & $\begin{array}{l}\text { Cost } \\
\text { (USD) }\end{array}$ & Strategies \\
\hline \multicolumn{6}{|l|}{ ENERGY } \\
\hline $\begin{array}{l}\text { Energy generation: } \\
\text { Imported electricity }\end{array}$ & $\begin{array}{l}\text { GS - Gas for Gaza sub-project: } \\
161 \mathrm{KV} \text { line }\end{array}$ & $\begin{array}{l}100 \mathrm{MW} \text { extra electricity } \\
\text { imported }\end{array}$ & 2020 & & $\mathrm{PI}, \mathrm{ES}, \mathrm{ID}$ \\
\hline \multirow[t]{6}{*}{ Energy generation: Gas } & WB - Jenin Power Plant & $450 \mathrm{MW}$ gas power plant & 2020 & $\$ 600 m$ & $\mathrm{PI}, \mathrm{SQ}, \mathrm{ES}, \mathrm{ID}$ \\
\hline & $\begin{array}{l}\text { GS - Gas for Gaza pipeline and } \\
\text { GPP conversion }\end{array}$ & $\begin{array}{l}80 \mathrm{MW} \text { extra electricity, reduced } \\
\text { energy costs }\end{array}$ & 2020 & $\$ 93 m$ & $\mathrm{PI}, \mathrm{SQ}, \mathrm{ES}, \mathrm{ID}$ \\
\hline & $\begin{array}{l}\text { GS - Gas for Gaza sub-project: } \\
\text { Power station Phase I }\end{array}$ & $\begin{array}{l}150 \mathrm{MW} \text { extra electricity } \\
\text { generated }\end{array}$ & 2023 & $\$ 155 m$ & PI, ES, ID \\
\hline & $\begin{array}{l}\text { GS - Gas for Gaza sub-project: } \\
\text { Power station Phase II }\end{array}$ & $\begin{array}{l}300 \mathrm{MW} \text { extra electricity } \\
\text { generated }\end{array}$ & 2027 & $\$ 320 m$ & $\mathrm{PI}, \mathrm{ID}$ \\
\hline & GS - Gaza Marine gas field & Supply of gas owned by Palestine & 2025 & $\sim \$ 1$ bil & $\mathrm{PI}, \mathrm{ID}$ \\
\hline & WB - Hebron Power Plant & 200 MW CCGT power plant & 2025 & & PI, ID \\
\hline \multirow[t]{4}{*}{ Energy generation: Solar } & GS - Gaza Solar Cells & $30 \mathrm{MW}$ & 2016 & & $\mathrm{PI}, \mathrm{SQ}, \mathrm{ES}, \mathrm{ID}$ \\
\hline & WB - Solar PV expansion phase 1 & $5.7 \mathrm{MW}$ & 2020 & & $\mathrm{PI}, \mathrm{SQ}, \mathrm{ES}, \mathrm{ID}$ \\
\hline & PAL - Solar PV expansion phase 2 & $35 \mathrm{MW}$ & 2023 & & PI, ES, ID \\
\hline & PAL - Solar PV expansion phase 3 & $110 \mathrm{MW}$ & 2025 & & $\mathrm{PI}, \mathrm{ES}, \mathrm{ID}$ \\
\hline \multirow[t]{2}{*}{$\begin{array}{l}\text { Energy distribution: } \\
\text { Electricity network }\end{array}$} & $\begin{array}{l}\text { GS - Gaza Electricity Network } \\
\text { Rehabilitation }\end{array}$ & $\begin{array}{l}\text { Improve reliability and } \\
\text { performance }\end{array}$ & 2020 & $\$ 133 m$ & $\mathrm{PI}, \mathrm{SQ}, \mathrm{ES}, \mathrm{ID}$ \\
\hline & $\begin{array}{l}\text { WB - Transmission network } \\
\text { enhancement }\end{array}$ & $\begin{array}{l}\text { Improve reliability and } \\
\text { performance }\end{array}$ & 2025 & $\$ 45 m$ & PI, ID \\
\hline \multicolumn{6}{|l|}{ WATER } \\
\hline \multirow{3}{*}{$\begin{array}{l}\text { Water supply: } \\
\text { Desalination }\end{array}$} & GS - STLV desalination projects & $7.3 \mathrm{MCM}$ per year & 2017 & & $\mathrm{PI}, \mathrm{SQ}, \mathrm{ES}, \mathrm{ID}$ \\
\hline & $\begin{array}{l}\text { GS - Gas for Gaza (G4G) } \\
\text { Desalination plant Phase } 1\end{array}$ & $55 \mathrm{MCM}$ extra water per year & 2025 & $\$ 500 \mathrm{~m}$ & PI, ES, ID \\
\hline & $\begin{array}{l}\text { GS - Gas for Gaza (G4G) } \\
\text { Desalination plant Phase } 2\end{array}$ & $30 \mathrm{MCM}$ extra per year & 2030 & & $\mathrm{PI}, \mathrm{ES}, \mathrm{ID}$ \\
\hline \multirow[t]{3}{*}{ Water supply: Imports } & GS - Imports from Israel Phase 1 & $5 \mathrm{MCM}$ per year & 2017 & & $\mathrm{PI}, \mathrm{SQ}, \mathrm{ES}, \mathrm{ID}$ \\
\hline & GS - Imports from Israel Phase 2 & 10 MCM per year & 2020 & & $\mathrm{PI}, \mathrm{SQ}, \mathrm{ES}, \mathrm{ID}$ \\
\hline & $\begin{array}{l}\text { PAL - Red Sea-Dead Sea Water } \\
\text { Conveyor Project }\end{array}$ & $16 \mathrm{MCM}$ to $\mathrm{WB}$ & 2030 & & $\mathrm{PI}, \mathrm{ID}$ \\
\hline \multicolumn{6}{|l|}{ WASTEWATER } \\
\hline \multirow{4}{*}{$\begin{array}{l}\text { Water treatment: New } \\
\text { plants }\end{array}$} & GS - Northern WWTP & $9-18 \mathrm{MCM} / \mathrm{yr}$ & 2018 & & PI, SQ, ES, ID \\
\hline & GS - Southern WWTP & $16 \mathrm{MCM} / \mathrm{yr}$ & 2020 & & $\mathrm{PI}, \mathrm{ES}, \mathrm{ID}$ \\
\hline & GS - Central WWTP & $65 \mathrm{MCM} / \mathrm{yr}$ & $2030 ?$ & & $\mathrm{PI}, \mathrm{ID}$ \\
\hline & $\begin{array}{l}\text { WB - Hebron Regional } \\
\text { Wastewater Management } \\
\text { Project - Phase } 1\end{array}$ & $5.5 \mathrm{MCM} / \mathrm{yr}$ & 2023 & $\$ 62 m$ & $\mathrm{PI}, \mathrm{ID}$ \\
\hline \multicolumn{6}{|l|}{ TRANSPORT } \\
\hline Transport: Rail & $\begin{array}{l}\text { WB - } 36 \mathrm{~km} \text { railway between } \\
\text { Nablus and Ramallah }\end{array}$ & Increased public mobility & 2025 & $\$ 150 m$ & PI, ID \\
\hline Gaza Sea \& Airport & $\begin{array}{l}\text { GS - Seaport \& single runway } \\
\text { airport }\end{array}$ & Increased international mobility & 2025 & $\sim \$ 5 b n$ & $\mathrm{PI}, \mathrm{ID}$ \\
\hline West Bank Airport & WB - Single runway airport & Increased international mobility & 2030 & $\sim \$ 3 b n$ & $\mathrm{PI}, \mathrm{ID}$ \\
\hline \multicolumn{6}{|l|}{ SOLID WASTE } \\
\hline \multirow[t]{4}{*}{$\begin{array}{l}\text { New waste management } \\
\text { facilities }\end{array}$} & $\begin{array}{l}\text { GS - Solid Waste Management } \\
\text { Project }\end{array}$ & 300,000 tons per year & 2020 & $\$ 35 m$ & $\mathrm{PI}, \mathrm{ES}, \mathrm{ID}$ \\
\hline & $\begin{array}{l}\text { WB - Southern West Bank Solid } \\
\text { Waste Management }\end{array}$ & $\begin{array}{l}100 \% \text { of municipal waste from } \\
700,000 \text { people }\end{array}$ & 2016 & $\$ 20 m$ & PI, SQ, ES, ID \\
\hline & WB - Jericho - Cell 1 expansion & $\begin{array}{l}\text { Mgmt of municipal waste from } \\
50,000 \text { people }\end{array}$ & 2017 & $\$ 3.1 \mathrm{~m}$ & $\mathrm{PI}, \mathrm{SQ}, \mathrm{ES}, \mathrm{ID}$ \\
\hline & $\begin{array}{l}\text { WB - Solid waste management } \\
\text { Ramallah/Al Bireh }\end{array}$ & $\begin{array}{l}\text { New sanitary landfill replacing } 83 \\
\text { dumpsites }\end{array}$ & 2020 & $\$ 12 m$ & PI, ID \\
\hline
\end{tabular}


- Abu Hamed, T., Flamm, H., Azraq, M. (2012) Renewable energy in the Palestinian Territories: opportunities and challenges. Renewable and Sustainable Energy Reviews 16, 1082-1088.

- Abusharbak, N., (2004) Development of Wastewater Treatment Tariff System. A Case Study of AlBireh Wastewater Treatment Plant, Water Engineering. Birzeit University, Palestine.

- Afifi, S. (2006) Wastewater reuse status in the Gaza Strip, Palestine. International Journal of Environment and Pollution 28, 76-86.

- Bank, W. (2018) Beyond Scarcity : Water Security in the Middle East and North Africa. MENA Development Report;. Washington, DC: World Bank https://openknowledge.worldbank.org/handle/10986/27659 License: CC BY 3.0 IGO.

- Bergaoui, K., Mitchell, D., Zaaboul, R., McDonnell, R., Otto, F., Allen, M. (2015) The contribution of human-induced climate change to the drought of 2014 in the southern Levant region. In "Explaining Extremes of 2014 from a Climate Perspective". Bulletin of American Meteorological Society 96, S5-S9.

- Bohannon, J. (2006) Running out of water - and time. Science 313, 1085-1087.

- Brooks, D., Trottier, J. (2010) Confronting water in an Israeli-Palestinian peace agreement. Journal of Hydrology 382, 103-114.

- Brown, O., Crawford, A., (2009) Rising temperatures, rising tensions: climate change and the risk of violent conflict in the Middle East. International Institute for Sustainable Development, Accessed from http://www.iisd.org/library/rising-temperatures-rising-tensions-climate-changeand-risk-violent-conflict-middle-east on 17/4/2016.

- Christensen, J.H., Hewitson, B., Busuioc, A., Chen, A., Gao, X., Held, I., Jones, R., Kolli, R.K., Kwon, W.-T., Laprise, R., Magaña Rueda, V., Mearns, L., Menéndez, C.G., Räisänen, J., Rinke, A., Sarr, A., Whetton, P., (2007) Regional climate projections., in: Solomon, S., Qin, D., Manning, M., Chen, A., Marquis, M., Averyt, K.B., Tignor, M., Miller, H.L. (Eds.), Climate Change 2007: The Physical Science Basis. Contribution of Working Group I to the Fourth Assessment Report of the Intergovernmental Panel on Climate Change, Cambridge, United Kingdom and New York, NY, USA.

- D-Waste, (2014) Country report on the solid waste management in Occupied Palestinian Territories. Deutsche Gesallschaft fur International Zusammenarbeit (GIZ), Germany.

- De Meij, A., Vinuesa, J.-F., Maupas, V., Waddle, J., Price, I., Yaseen, B., Ismail, A. (2016) Wind energy resource mapping of Palestine. Renewable and Sustainable Energy Reviews 56, 551-562.

- Diaz, L.F. (2017) Waste management in developing countries and the circular economy. Waste Management \& Research 35, 1-2.

- Dotan, P., Godinger, T., Odeh, W., Groisman, L., Al-Khateeb, N., Abed Rabbo, A., Tal, A., Arnon, S. (2016) Occurrence and fate of endocrine disrupting compounds in wastewater treatment plants in Israel and the Palestinian West Bank. Chemosphere 155, 86-93.

- El Baba, M., Kayastha, P., De Smedt, F. (2015) Landfill site selection using multi-criteria evaluation in the GIS interface: a case study from the Gaza Strip, Palestine. Arabian Journal of Geosciences 8, 7499-7513.

- Eting, S., (2015) Robust Solutions for Unstable Regions. Wastewater systems in the Gaza Strip by 2030, Geography. University of Oxford.

- Evans, S., (2015) A resilient path of sustainable development? An assessment of the potential for solar PV in the Gaza Strip by 2030, Geography. University of Oxford.

- EWASH, (2015) Water and sanitation in Palestine, in: Emergency, Water, Sanitation and Hygiene (EWASH) group, Accessed from http://www.ewash.org/sites/default/files/inoptfiles/160314\%20\%2OWATER\%20AND\%20SANITATION\%20IN\%20PALESTINE.pdf on 15/4/2016 (Ed.).

- Fatta, D., Salem, Z., Mountadar, M., Assobhei, O., Loizidou, M. (2004) Urban Wastewater Treatment and Reclamation for Agricultural Irrigation: The situation in Morocco and Palestine. Environmentalist 24, 227-236. 
- Gabriel, K.J., El-Halwagi, M.M., Linke, P. (2016) Optimization across the Water-Energy Nexus for Integrating Heat, Power, and Water for Industrial Processes, Coupled with Hybrid ThermalMembrane Desalination. Industrial \& Engineering Chemistry Research 55, 3442-3466.

- Garb, Y. (1998) The challenge of sustainable transport for Israel and Palestine. Palestine-Israel Journal 5.

- Ghaffour, N., Missimer, T.M., Amy, G.L. (2013) Technical review and evaluation of the economics of water desalination: Current and future challenges for better water supply sustainability. Desalination 309, 197-207.

- Haddad, M., (2009) Palestinian water rights: past, present and future, in: Messerschmid, E. (Ed.), Water: Values and Rights. Palestine Academy Press, Ramallah, pp. 41-52.

- Hall, J.W., Tran, M., Hickford, A.J., Nicholls, R.J. (eds) (2016a) The future of national infrastructure. A system-of-systems approach. Cambridge University Press., Cambridge, UK.

- Hall, J.W., Tran, M., Hickford, A.J., Nicholls, R.J. (2016b) The Future of National Infrastructure. A System-of-Systems Approach. Cambridge University Press, Cambridge.

- Hattem, B., (2014) West Bank landfills acting as pits for foreign aid, Middle East Eye. Middle East Eye.

- Henderson, S., (2014) Natural gas in the Palestinian Authority: the potential of the Gaza marine offshore field, Mediterranean Policy Program, Eastern Mediterranean Energy Project, Policy Brief. The German Marshall Fund of the United States.

- Hickford, A.J., Nicholls, R.J., Otto, A., Hall, J.W., Blainey, S.P., Tran, M., Baruah, P. (2015) Creating an ensemble of future strategies for national infrastructure provision. Futures 66, 13-24.

- Ibrik, E., (2009) Energy profile and the potential of renewable energy sources in Palestine, in: Mason, M., Mor, A. (Eds.), Renewable Energy in the Middle East. Springer, Dordrecht, pp. 71-89.

- ICE, (2016) National Needs Assessment. A Vision for UK Infrastructure. Institution of Civil Engineers, London, UK.

- IMF, (2015) West Bank and Gaza. Report to the Ad hoc Liaison Committee. International Monetary Fund.

- IMF, (2016) West Bank and Gaza. Report to the Ad hoc Liaison Committee. International Monetary Fund.

- Isaac, J., Khair, A., Hilal, J., (2011) Status of the environment in the occupied Palestinian territories - a human rights based approach. The Applied Research Institute - Jerusalem (ARIJ), Accessed from http://www.arii.org/files/admin/SOER 2011 - English Summary.pdf on 12/4/2016.

- Isaac, J., Khalil, M., Rishmawi, K., Dabouqi, A., Marinelli, L., (2015) The economic cost of the Israeli occupation of the occupied Palestinian territories. The Applied Research Institute - Jerusalem (ARIJ), Accessed from

http://www.arij.org/files/arijadmin/2016/The Economic Cost of the Israeli occupation Report upd.pdf on 20/3/2016.

- Isaac, J., Rishmawi, K., (2015) Status of the environment in the state of Palestine 2015. The Applied Research Institute - Jerusalem (ARIJ), Accessed from http://www.arij.org/files/arijadmin/2016/Final SOER 2015 opt r.pdf on 20/12/2016.

- Isaac, J., Safar, A., Rishmawi, K., Darwish, G., Sbeih, S., Qabajah, A., Weinroth, T., Nassar, A., Bannourah, E., (2005) Analysis of waste management policies in Palestine. The Appied Research Institute - Jerusalem (ARIJ), Accessed from http://www.arij.org/files/admin/20052 Analysis of Waste Management Policies in Palestine.pdf on 2/4/2016.

- Ives, M.C., Hickford, A.J., Adshead, D., Thacker, S., Hall, J.W., Nicholls, R.J., Abu Ayyash, M., Sway, T., Jones, R., O'Regan, N., (2018) A Fast Track Analysis of Infrastructure Provision in Palestine. University of Oxford, Infrastructure Transitions Research Consortium, United Nations Office of Project Services, ITRC website.

- Juaidi, A., Montoya, F.G., Ibrik, I.H., Manzano-Agugliaro, F. (2016) An overview of renewable energy potential in Palestine. Renewable and Sustainable Energy Reviews 65, 943-960. 
- Kabat, P., van Vierssen, W., Veraart, J., Vellinga, P., Aerts, J. (2005) Climate proofing the Netherlands. Nature 438, 283.

- Kanyoka, P., Eshtawi, T., (2012) Analyzing the trade-offs of wastewater re-use in agriculture: an analytical framework. Center for Development Research, University of Bonn, Accessed from http://www.zef.de/fileadmin/downloads/forum/docprog/Termpapers/2012 1Tamer Phillipa.pdf on 10/5/2016.

- Ludwig, R., (2016) Climate induced changes on water and security, study sites: Gaza Strip. LudwigMaximilians-Universitaet Muenchen, Department of Geography.

- MAS, (2014) The electricity sector: current status and the need for reform. Final report: Round Table Discussion No. 4. . Palestine Economic Policy Research Institute, Accessed on 8th June 2016, at: http://www.mas.ps/files/server/20141911184358-1.pdf.

- Masood, T., McFarlane, D.C., Schooling, J., Fielding, A., Downes, J., (2016) Future-proofing assessment of infrastructure assets, Transforming the Future of Infrastructure through Smarter Information: Proceedings of the International Conference on Smart Infrastructure and Construction, 27-29 June 2016, University of Cambridge, pp. 621-626.

- McNeill, L.S., Almasri, M.N., Mizyed, N. (2009) A sustainable approach for reusing treated wastewater in agricultural irrigation in the West Bank - Palestine. Desalination 248, 315-321.

- Ministry of Local Government, (2016) GeoMOLG - The Integrated Spatial Information System of The Ministry Of Local Government, in: Ministry of Local Government (Ed.).

- Modi, V., McDade, S., Lallement, D., Saghir, J., (2006) Energy services for the Millennium Development Goals. Energy Sector Management Assistance Programme, United Nations Development Programme, UN Millennium Project, and World Bank, Accessed from http://www.unmillenniumproject.org/documents/MP Energy Low Res.pdf on 3/6/2016, New York.

- MoPWH, (2012) Road sector in Palestine - achievements, needs, and hallenges. Ministry of Public Works and Housing

- Nassar, A.R. (2015) Strategies of sludge management in the Gaza Strip. Journal of Scientific Research \& Reports 5, 419-426.

- NationMaster, (2014) Motor vehicles per 1000 people. NationMaster.

- OCHA, (2016) Humanitarian bulletin: occupied Palestinian territory. United Nations, Office for the Coordination of Humanitarian Affairs, Accessed from https://www.ochaopt.org/documents/ocha opt the humanitarian monitor 20160105 englis h.pdf on $27 / 5 / 2016$.

- Office of the Quartet, (2016) Report for the Meeting of the Ad-Hoc Liaison Committee on Action in Support of Palestinian State-Building.

- Otto, A., Hall, J.W., Hickford, A.J., Nicholls, R.J., Alderson, D., Barr, S., Tran, M. (2014) A quantified system-of-systems modeling framework for robust national infrastructure planning.

- Ouda, O.K.M. (2013) Assessment of the environmental values of waste-to-energy in the Gaza Strip. Current World Environment 8, 355-364.

- Paltrade, (2010) Challenges facing ICT in Palestine. Paltrade, Accessed from http://siteresources.worldbank.org/INTWESTBANKGAZA/Resources/ChallengesFacingICTPalestine .pdf on 10/4/2016, Ramallah, Palestine.

- Pant, R., Thacker, S., Hall, J.W., Alderson, D., Barr, S. (2018) Critical infrastructure impact assessment due to flood exposure. Journal of Flood Risk Management 11, 22-33.

- PCBS, (2010a) Number of localities and population who don't have wastewater network in the Palestinian territory by Governorate, 2010.

- PCBS, (2010b) Number of registered Palestinian refugees by sex and country, 2010. Accessed from http://www.pcbs.gov.ps/Portals/ Rainbow/Documents/PalDis-REFUGEE-2010E.htm on 25/3/2016.

- PCBS, (2014a) Annual available water quantity in Palestine by region and source, 2014. Accessed from http://www.pcbs.gov.ps/Portals/ Rainbow/Documents/water-E2-2014.htm on 6/4/2016. 
- PCBS, (2014b) Quantity of water supply for domestic sector, water consumed, total losses, population and daily allocation per capita in Gaza Strip by Governorate, 2014. Accessed from http://www.pcbs.gov.ps/Portals/ Rainbow/Documents/water-E8-2014.htm on 10/4/2016.

- PCBS, (2014c) Quantity of water supply for domestic sector, water consumed, total losses, population and daily allocation per capita in the West Bank by Governorate, 2014. Accessed from http://www.pcbs.gov.ps/Portals/ Rainbow/Documents/water-E7-2014.htm on 10/4/2016.

- PCBS, (2014d) Road network length in Palestine by Governorate, region and road type, 2014. Accessed from http://www.pcbs.gov.ps/Portals/ Rainbow/Documents/eTrans annual9 2014.htm on 22/3/2016.

- PCBS, (2014e) Transportation and communication statistics in Palestine, annual report 2014. State of Palestine, Palestine Central Bureau of Statistics.

- PCBS, (2015a) Amount of consumed water in the household sector in Palestine (thousand cubic meter) and household monthly average consumption of water (cubic meter) by region, 2015. Accessed from http://www.pcbs.gov.ps/Portals/ Rainbow/Documents/HHE\%202015\%20e\%202.htm on 4/4/2016.

- PCBS, (2015b) Annual rainfall quantity in Palestine by year and station location, 2007-2015 (mm). Accessed from http://www.pcbs.gov.ps/Portals/ Rainbow/Documents/Metorolgical-2015Tab04E.htm on 30/1/2017.

- PCBS, (2015c) Distribution of localities in Palestine by availability of wastewater network and Governorate, 2015. Accessed from http://www.pcbs.gov.ps/Portals/ Rainbow/Documents/Local\%2014E.htm on 16/5/2016.

- PCBS, (2015d) Energy balance tables for Palestine, 2015. Accessed from http://www.pcbs.gov.ps/Portals/ Rainbow/Documents/tables\%202015.xlsx on 30/1/2017.

- $\quad$ PCBS, (2015e) Evaporation quantity $(\mathrm{mm})$ in the West Bank by month and station location, 2015. Accessed from http://www.pcbs.gov.ps/Portals/ Rainbow/Documents/Metorolgical-2015Tab07E.htm on 30/1/2017.

- PCBS, (2015f) Number of localities in Palestine by wastewater disposal method and Governorate, 2015. Accessed from http://www.pcbs.gov.ps/Portals/ Rainbow/Documents/Local\%2016E.htm on 22/4/2016.

- PCBS, (2015g) Palestinians at the end of 2015. Accessed from http://www.pcbs.gov.ps/Downloads/book2176.pdf on 6/6/2016.

- PCBS, (2015h) Transportation and Communications Statistics in Palestine: Annual Report 2014. State of Palestine Palestinian Central Bureau of Statistic, Ramallah-Palestine.

- PCBS, (2016) Transportation and Communications Statistics in Palestine: Annual Report 2015. State of Palestine Palestinian Central Bureau of Statistic, Ramallah-Palestine.

- Poppert, D., (2017) The Palestinian Diaspora: A History of Dispossession.

- PWA, (2011) The Gaza Emergency Technical Assistance Programme (GETAP) on water supply to the Gaza Strip, Component 1 - The comparative study of options for an additional supply of water for the Gaza Strip (CSO-G). Palestinian Water Authority, Ramallah, Palestine.

- PWA, (2012) Annual status report on water resources, water supply, and wastewater in the occupied State of Palestine. State of Palestine Palestinian Water Authority, Accessed from http://www.pwa.ps/userfiles/file/\%D8\%AA\%D9\%82\%D8\%A7\%D8\%B1\%D9\%8A\%D8\%B1/Annual\% 20Water\%20Status\%20report\%202011.pdf on 1/7/2016.

- PWA, (2014) Strategic water resources and transmission plan. State of Palestine Palestinian Water Authority, Accessed from http://www.pwa.ps/userfiles/file/\%D8\%AA\%D9\%82\%D8\%A7\%D8\%B1\%D9\%8A\%D8\%B1/Strategic \%20Action\%20Plan.pdf on 14/7/2016.

- PWA, (2015) Gaza Strip: desalination facility project: necessity, politics and energy. State of Palestine Palestinian Water Authority.

- Ramírez, R., Selin, C. (2014) Plausibility and probability in scenario planning. foresight 16, 54-74. 
- Sa'di, M.G.M.A., Reuse-Recycling Options for Municipal Solid Waste in Zahrat Al-Finjan Landfill Environmental Engineering, Faculty of Graduate Studies. An-Najah National university, Nablus, Palestine. .

- Sanchez, R., (2017) Israeli minister proposes building an artificial island off the coast of Gaza The Telegraph, 28th June 2017. The Telegraph, United Kingdom,

http://www.telegraph.co.uk/news/2017/06/28/israeli-minister-proposes-building-artificial-islandcoast-gaza/.

- Shadeed, S., Almasri, M. (2010) Application of GIS-based SCS-CN method in West Bank catchments, Palestine. Water Science and Engineering 3, 1-13.

- Shomar, B. (2011) Water scenarios in the Gaza Strip, Palestine: thirst, hunger and disease. International Journal of Environmental Studies 68, 477-493.

- Shomar, B., Abu Fakher, S., Yahya, A. (2010) Assessment of groundwater quality in the Gaza Strip, Palestine using GIS mapping Journal of Water Resource and Protection 2, 93-104.

- Siddiqi, A., Anadon, L.D. (2011) The water-energy nexus in Middle East and North Africa. Energy Policy 39, 4529-4540.

- State of Palestine, (2015) Palestine 2025, Palestine 2050. Envisioning Palestine. State of Palestine National Spatial Plan. .

- Suisman, D., Steven Simon, Glenn Robinson, C. Ross Anthony, Schoenbaum, M., (2005) The Arc: A Formal Structure for a Palestinian State RAND Corporation. Assessed from https://www.rand.org/pubs/monographs/MG327-2.html on 13/4/2017, Santa Monica, CA.

- UN-ESCWA, BGR, (2013) Inventory of Shared Water Resources in Western Asia, Chapter 20: Coastal Aquifer Basin. ESCWA, Accessed from https://waterinventory.org on 31/12/2017.

- UN Human Rights, UN Habitat, World Health Organization, (2010) The right to water. United Nations and World Health Organization, Accessed from http://www.ohchr.org/Documents/Publications/FactSheet35en.pdf on 25/5/2016.

- UNEP, (2003) Desk study on the environment in the occupied Palestinian territories. United Nations Environment Programme, Accessed from http://www.unep.org/download file.multilingual.asp?FilelD=105 on 3/5/2016.

- UNISPAL, (2007) West Bank and Gaza energy sector review. UNISPAL/World Bank.

- UNRWA, (2012) Gaza in 2020. A liveable place? United Nations Country Team (UNCT), Accessed from http://www.unrwa.org/userfiles/file/publications/gaza/Gaza\%20in\%202020.pdf on 24/6/2016, Jerusalem.

- van Vliet, M.T.H., Franssen, W.H.P., Yearsley, J.R., Ludwig, F., Haddeland, I., Lettenmaier, D.P., Kabat, P. (2013) Global river discharge and water temperature under climate change. Global Environmental Change 23, 450-464.

- Weibel, C., Elmughanni, S., (2014) A fresh solution to Gaza's water crisis. UNICEF.

- World Bank, (2009) Assessment of restrictions on Palestinian water sector development. International Bank for Reconstruction and Development / The World Bank, Accessed from http://siteresources.worldbank.org/INTWESTBANKGAZA/Resources/WaterRestrictionsReport18A pr2009.pdf on 22/5/2016, Washington, D.C.

- World Bank, (2014a) West Bank and Gaza Assessment and Action Plan to improve payment for electricity services in the Palestinian Territories. Study on Electricity Sector Contribution to Net Lending. GEEDR Middle East and North Africa.

- World Bank, (2014b) World Development Indicators (WDI). Accessed from http://databank.worldbank.org/data/reports.aspx?source=world-development-indicators on 20/4/2016.

- World Bank, (2015) West Bank and Gaza - sustainable water supply program project. World Bank Group, Washington D.C.

- World Bank, (2016) Telecommunication sector note in the Palestinian Territories: missed opportunity for economic development. Note for the Palestinian Ministry of Telecommunications and Information Technology. The World Bank Group, 
- World Bank, (2017) Securing Energy for Development in West Bank and Gaza. Summary Report. World Bank Group, ESMAP, N.Y.

- World Bank Group, (2018) West Bank and Gaza. Portfolio Snapshot April 2018, Washington, DC: World Bank http://documents.worldbank.org/curated/en/247051523908273274/pdf/125318WP-PUBLIC-Eng-World-Bank-Portfolio-Snapshot-spreads-04-2018.pdf.

- Zimmerman, B., Seid, R., Wise, M.L., (2006) The million person gap: the Arab population in the West Bank and Gaza. Begin-Sadat Center for Strategic Studies, Israel. 